\title{
HUKUKA UYGUNLUK NEDENLERINDE HATA (TCK m.30/3)
}

\section{Ali Tanju SARIGÜL*}

\section{$\ddot{O} Z$}

Hukuka uygunluk nedenlerinde hata, hukuka uygunluk nedenlerinin maddi koşullarında, hukuka uygunluk nedenlerinin varlığında ya da sinırında olabilmektedir.

Hukuka uygunluk nedenlerinde hatanın bu ayrım gözetilmeksizin 5237 sayıl TCK'nın 30/3 maddesinde "ceza sorumluluğunu kaldıran ya da azaltan nedenler" başlığı altında düzenlendiğini ve aynı ceza sorumluluğunu gerektirecek şekilde hüküm altına alındığını görmekteyiz. Hatanın kaçınılmaz olması durumunda failin hatasından yararlanacăğ belirtilmiş, kaçınılabilir olması durumuna ise bir hukuki sonuç bağlanmamıştır.

Hukuka uygunluk nedenlerinin maddi koşullarında yanılgıya düşülmesi durumunda söz konusu olan hata, failin tasavvuruna ilişkindir. Bu nedenle tipiklikte unsur hatası ile benzerlik gösterir ve kastı ortadan kaldırır. Hukuka uygunluk nedenlerinin varlığında hata durumunda ise, fail eyleminin hukuk düzeninin izin verdiği konusunda yanılgıya düştügünden, haksızlık yanılgısı gibi kusurluluğu etkileyen bir etkileyen bir hata söz konusudur.

TCK m.27/1'de ise hukuka uygunluk nedenlerinde sinırın kast olmaksızın aşılması halindeki ceza sorumluluğu düzenlenmektedir. Bu düzenleme hatanın maddi unsur ya da izin normunda olması dikkate alınarak kastı ya da kusurluluğu etkileyebilmektir.

Anahtar Kelimeler: Hukuka Uygunluk Nedenlerinde Hata, Maddi Koşullarda Hata, Haksızlık Yanılgısı, Kusur Teorisi, Kaçınılmazlık.

\section{ERROR IN THE CAUSES OF THE COMPLIANCE WITH LAWS (TURKISH PENAL CODE ART. 30/3)}

\section{ABSTRACT}

Error in the causes of compliance with laws may be in the objective conditions of the causes or in the presence or in the limit of the causes of comliance with laws.

* Dr. Öğr.Üyesi, Hasan Kalyoncu Üniversitesi Hukuk Fakültesi, Ceza ve Ceza Muhakemesi Hukuku Anabilim Dalı Öğretim Üyesi, E-posta: atanju.sarigul @ hku.edu.tr

ORCID ID: 0000-0002-4112-0311

DOI : 10.34246/ahbvuhfd. 775422

Yayın Kuruluna Ulaştığı Tarih : 06/02/2020

Yayınlanmasının Uygun Görüldüğü Tarih: 20/07/2020 
We see that the error in the causes of compliance with the law is regulated under the title "which remove or reduce the criminal liabilities" in Article 30/3 of the Turkish Penal Code (Law No.5237) without distinction and requires the same criminal responsibility. If the error is inevitable, it is stated that the perpetrator will benefit from the error, and if it is avoidable, there is no legal result.

In the objective conditions of the causes of the compliance with law, the error relates to the intention of the perpetrator. Therefore, it is similar to the error of the objective element in typeness and removes the intent. In the event of an error in the presence of causes of compliance with the law, the perpetrator was mistaken in the fact that the legal order of the offense allowed. Herewith, there is an error affecting the culpability, such as injustice error.

In Article 27/1 of the Turkish Penal Code, criminal liability is regulated in case of exceeding the limit without intent for causes of compliance with the law. This regulation is to be able to affect intent or culpabilty, taking into account whether the error is in the objective element or the norm of permits.

Key Words: Error of causes of compliance with the law; error of the objective elements; injustice error; the culpability theory; inevitable.

\section{GİRIŞ}

TCK'daki düzenlemeye göre kastı kaldıran hata; suçun maddi unsurlarında (m.30/1), nitelikli unsurlarında (m.30/2) ya da hukuka uygunluk sebeplerinin maddi koşullarında (m.30/3) olabilir. Hata kavramını ve kastı kaldıran hata hallerinden ilkini teşkil eden suçun maddi unsurlarında hata konusunu önceki makalemizde incelemeye çalışmıştık ${ }^{1}$.

Makalemizin konusunu, kapsamının genişliği nedeniyle önceki makalede ele alamadığımız ve kastı kaldıran hatalardan bir diğeri olan hukuka uygunluk nedenlerinde hata konusu teşkil etmektedir.

Hukuka uygunluk nedenlerinde hata konusunu alt başlıklara ayırmak suretiyle incelediğimizde, öğretide en tartışmalı alanın hukuka uygunluk nedenlerinin maddi koşullarında hata konusunda olduğunu görmekteyiz. Bu konuAlman Ceza Hukukunda hüküm bulunmaması nedeniyle tipiklikteki unsur hatası hükümlerinin kıyasen uygulanması suretiyle çözüme kavuşturulmuştur.

SARIGÜL, s.663-693.

326 Ankara Hacı Bayram Veli Üniversitesi Hukuk Fakültesi Dergisi C. XXIV, Y. 2020, Sa. 3 
Türk Ceza Kanunu'nda ise, Alman Hukukunun aksine normatif düzenleme bulunmaktadır. Ancak bu düzenleme öğretide farklı görüşlerin oluşmasına engel olamamıştır. Makalemizde Alman öğretisindeki katı kusur, suçun olumsuz unsurları ve sinırlı kusur teorileri kapsamında bu hukuki soruna yönelik bir analiz yapılmaya çalışılmıştır.

Hukuka uygunluk nedenlerinin varlığında ve sinırlarında hata konusu ise makalemizin diğer alt başlıklarını oluşturmaktadır. Alman Hukukunda izin hatas1 olarak nitelendirilen bu hata hallerinde fail, hukuka uygunluk nedeninin mevcut zannetmekte ya da sınırlarını olduğundan geniş kabul ederek, hareketini gerçekleştirmektedir.

Hata konusundaki diğer başlık olan "haksızlık yanılgısı" konusunu ise kapsamının genişliği dikkate alınarak bir sonraki çalışmada incelemeyi düşündügümüzden, bu çalışmanın dışında bıraktık.

Hata konusunda kavramsal konularda tekrara düşmemek için, önceki makalede değinilmiş olan konular yeniden irdelenmeyecek, atıfla yetinilecektir.

\section{Ceza Sorumluluğunu Kaldıran Veya Azaltan Nedenlerde Hata (m.30/3)}

TCK'nın 30. maddesinin 3. fikras1 “Ceza sorumluluğunu kaldıran veya azaltan nedenlere ait koşulların gerçekleştiği hususunda kaçınılmaz bir hataya düşen kişi, bu hatasından yararlanır." düzenlemesini içermektedir.

Düzenlemedeki koşullar ile kastedilenin maddi koşullar olduğu konusunda bir tereddüt bulunmamaktadır. Ceza sorumluluğunu kaldıran ve azaltan sebeplerin maddi koşullarında hata Alman Ceza Kanunu'nda düzenlememiş olup, bu yönüyle Türk Ceza Kanunu'ndaki düzenleme ile farkl11ık göstermektedir².

Madde başlığı dikkate alındığında "Ceza sorumluluğunu kaldıran veya azaltan nedenlerin" neler olduğunun ortaya konulmas1 gerekmektedir. Kanun'un birinci kitabının ikinci kısmının ikinci bölümünde düzenlenen söz konusu nedenler incelendiğinde; meşru savunma ve zorunluluk hali (m.25), hakkın kullanılması ve ilgilinin rızası (m.26) ve kanun hükmünü icra

\footnotetext{
2 Alman Ceza Kanunu'nda (Strafgesetzbuch-StGB); 16. maddede "suç tipindeki unsurlarda hata (Irrtum über Tatumstände)", 17. maddede ise ;" yasak hatası (Verbotsirrtum)" düzenlenmiştir. Ancak bu konu hataya ilişkin düzenleme içinde yer almamaktadır.
} 
(m.24) gibi bazı hukuka uygunluk nedenlerinin sayıldığı, yaş küçüklüğü, akıl hastalı̆̆ı, sağır-dilsizlik, sarhoşluk ve uyuşturucu madde gibi isnat yeteneğini kaldıran veya azaltan nedenlere ve bunların yanında kusurluluğu kaldıran (m.28; m.30/4) ya da etkileyen nedenlere (m.29) yer verildiği görülmektedir.

Hukuka uygunluk nedenlerinin maddi koşullarında hata ile ceza sorumluluğunu ortadan kaldıran nedenlerin aynı madde altında düzenlenmesi nedeniyle, kanunun lafzi ve sistematik yorumu dikkate alındığında aynı hukuki sonucun doğmasını gerektirecektir.

Ancak makalede aşağıda da değinileceği üzere hukuka uygunluk nedenlerinin maddi koşullarında hatanın hukuki niteliği ve dolayısıyla hukuki sonucu öğretide tartışmalıdır. İlk bakışta düzenleme açı görülebilir. Kanun koyucu hukuka uygunluk nedenlerinin maddi koşullarında kaçınılmaz hataya düşülmesi durumunda, aynı cezai sorumluluğu kaldıran nedenlerde olduğu gibi bu hatasından yararlanacağını öngörmekle birlikte, buna bağlanan sonucun ne olduğu, bu hatanın kast üzerinde mi etkili olacağı, yoksa kusurluluğu mu ortadan kaldıracağı tartışmalıdır. Uygulanacak yorum hukuki sonucun ve uygulanacak kanun maddesinin bile farklı olmasına neden olacak niteliktedir.

Hukuka uygunluk nedenlerinin maddi koşullarında hatanın kasit üzerinde etkili olduğu sonucuna vardığımız takdirde 30. maddenin 1. fikras1 uyarınca uygulama yapılacak, suçun maddi unsurlarında hataya ilişkin ceza sorumluluğu ile aynı hukuki sonuca ulaşılacaktır. Kasıt değil de kusur üzerinde etkili olduğu, dolayısıyla hatanın kaçınılmaz olması halinde kusurluluğun ortadan kalkacağı sonucuna vardığımız takdirde ise haksızlık yanılgısını (yasak yanılgisı) $^{3}$ düzenleyen 30.maddenin 4. fikrasının uygulanmasını gerektirecektir ${ }^{4}$.

Ceza Muhakemesi Kanunu'nun 223.maddesi incelendiğinde hukuka uygunluk sebepleri ile kusurluluğu ortadan kaldıran sebeplere bağlanan hukuki sonuçların farklı olduğu görülmektedir. Yapılan yargılama sonucunda hukuka uygunluk sebepleri bulunduğuna karar verildiği takdirde beraat kararı verilecek, kusurluluğu ortadan kaldıran sebeplerden birisinin bulunduğuna ilişkin bir yargıya varılması durumunda ise verilecek karar beraat kararı değil, ceza verilmesine yer olmadığına ilişkin karar olacaktır5.

3 Haksızlık yanılgısı Alman Ceza Kanunu'nun 17. maddesinde “yasak yanılgısı” başlığı altında düzenlenmiştir.

4 Aynı yönde GÖKTÜRK, (2014), s. 8.

5 KEÇELIOOĞLU, (2010), s.317-318.

328 Ankara Hacı Bayram Veli Üniversitesi Hukuk Fakültesi Dergisi C. XXIV, Y. 2020, Sa. 3 
Ezcümle, yargılama sonucu verilecek hükmün bile farklı olduğu dikkate alındığında düzenlemenin sorun doğurabileceği açıktır.

Diğer taraftan niteliği gereği kusurluluğu ortadan kaldıran nedenlerin maddi koşullarında yanılma konusunda açık bir düzenlemeye ihtiyaç bulunup bulunmadığı da ayrı bir tartışma konusudur. Örneğin zorunluluk halinin koşulları konusunda hataya düşen kişinin ceza sorumluluğu m.30/3'deki düzenleme bulunmadığ takdirde nasıl çözümlenirdi?

Böyle bir düzenleme bulunmasa idi, kanaatimizce kusur teorisi kapsamında, somut vakada haksızlı̆̆ın mevcut olduğu, ancak hatanın kaçınılmaz olması halinde failin bu hatasından faydalanacağı sonucuna varılabilirdi ${ }^{6}$.

Öğretide kusurluluğa ilişkin tüm nedenleri kapsayacak şekilde sadece kusurluluğu ortadan kaldıran sebepler ibaresi kullanıldığ 1 gibi ${ }^{7}$, kusurluluğu kaldıran sebeplerin yanında haklı olarak "kusurluluğu azaltan sebepler" kavramına da yer verildiği görülmektedir .

Alman Ceza Kanunundan farklılık arz eden Hükümet Tasarısının 23/3. maddesinin gerekçesi incelendiğinde; madde başlı̆̆ı ile uyumsuz olacak şekilde "kendisine kusur olarak isnadı mümkün olmayan bir hata dolayısıyla hukuka uygunluk nedenine ait koşullara uyduğunu sanan kimseye ceza verilmez" şeklindedir. Gerekçenin sadece hukuka uygunluk nedenlerinin koşullarına ilişkin hataya işaret ettiği, ceza sorumluluğunu kaldıran ya da azaltan nedenlere ilişkin bir açıklamada bulunmadığı anlaşılmaktadır.

Hukuka uygunluk nedenleri ile kusurluluğu etkileyen nedenlerin aynı bölümde düzenlenmesine ilişkin Özgenç'in; "TBMM Adalet Alt Komisyonunda yürütülen yeni TCK'ya ilişkin çalışmalar sırasında, bu kısımda birisi "hukuka uygunluk nedenleri", diğeri ise "kusurluluğu ortadan kaldiran veya azaltan neden" olarak bu ikinci bölümde yer alması yönünde öneride bulunmamıza rağmen, siyasi irade tarafindan bu Bölüm içinde bulunan 24, 25 ve 26. maddelerin konseptinde değişiklik yapılması uygun bulunmamıştır. $\mathrm{Bu}$ durum karşısında hiç olmazsa bölüm başlığının "hukuka uygunluk nedenleri" değil de "ceza sorumluluğunu ortadan kaldıran ya da azaltan nedenler" olarak değiştirilmesi yönünde bulunduğumuz ikinci öneri kabul görerek, söz konusu

\footnotetext{
6 GÖKTÜRK, (2014), s.9; DEĞİRMENCİ, s.162.

7 KEÇELİĞLLU, (2010), s.299 vd.

8 ÖZGENÇ, (2019), s.484.
} 
bölüm başlığı değiştirilmiştir". şeklindeki açıklamalarının da kanun koyucunun sübjektif yorumu bakımından dikkate alınması gerektiğini düşünmekteyiz9 .

Düzenlemeye ilişkin m.30/3'de hukuka uygunluk nedenlerinin ve kusurluluğu ortadan kaldıran sebeplerin maddi koşullarında bir ayrıma gidilmemiş olmasının, Kanun koyucu tarafindan, her iki hata durumunun kusurluluk kapsamında değerlendirilmesinin irade edilmesinin bir sonucu olduğu da ifade edilmektedir ${ }^{10}$.

Kanun koyucunun hukuka uygunluk nedenlerini "katı kusur teorisi"11 kapsamında kastın kapsamına dahil etmediği, kusurluluğun tespiti ile ceza sorumluluğunun tespitinin amaçlandığ d düşünülebilir mi?

Madde gerekçesinde; "somut olayda söz konusu nedenlerin gerçekleştiği hususunda hataya düşen kişi, bu hatasından yararlanabilecektir. Ancak bunun için hatanın kaçınılmaz olması gerekir. Hatanın kaçınılabilir olması durumunda ise kişi işlediği fiilden sorumlu tutulacak ve fakat bu hata temel cezanın belirlenmesinde göz önünde bulundurulacaktır." denmektedir ${ }^{12}$.

Gerekçeye göre, kaçınılmaz bir hata söz konusu ise kişi kusurlu kabul edilmeyecek, dolayısıyla herhangi bircezai sorumluluk doğmayacaktır. Hatanın kusurluluğu azaltan nedenlere ilişkin ve kaçınılmaz olması halinde ise, haksız tahrik örneğinde olduğu gibi, hükmolunacak cezada haksız tahrik hükümleri çerçevesinde cezada indirim yapılacaktır. Kusurluğu azaltan nedenlere ilişkin kaçınılabilir hata durumunda (Kanun'un gerekçesinden farklı olarak) kişi hatasından istifade edemeyecektir ${ }^{13}$. Hatanın hukuka uygunluk nedenleri ya

9 ÖZGENÇ, (2019), s.322.

10 KEÇELIOĞLU, (2010), s.315.

11 Die strenge Schuldtheorie

12 30. maddenin gerekçesi için bkz. https://www2.tbmm.gov.tr/d22/1/1-0593.pdf (erişim tarihi: 30.12.2019)

13 YCGK, 7.11.2019, E.2018/1-27, K.2019/644. “Ceza sorumluluğunu azaltan nedenlerden olan haksız tahrikin varlığı konusunda da hataya düșülebilir. Haksız tahrikin varlığ konusunda kaçınılmaz hataya düşen fail haksız tahrik hükmünden yararlanacaktır. Fakat burada hatanın kaçınılmaz olması zorunludur. Buna karşılık, hata kaçınılabilir bir hata ise, yani failin kişisel özellikleri göz önüne alındiğında, daha dikkatli ve özenli davranması durumunda hatasından kaçınabilecekse başka bir anlatımla hata meydana gelmeyecekse artık haksız tahrik hükümlerinden yararlanamayacaktır.

Öğretide bu konuya ilişkin olarak; “... örneğin, kendisine köy kahvesinde küfür eden B’yi kahve çıkışında dövmek için geçeceği yol üzerinde bekler. Yoldan geçenin görünüş olarak B'ye çok benzeyen C olduğunu gece karanlığının da etkisiyle fark etmeyip ona sopayla birkaç 
da kusurluluğu ortadan kaldıran nedenlere ilişkin olması durumunda ise temel cezanın tayininde dikkate alınacaktır.

Katı kusur teorisi koşullarda yanılmayı yasak hatası kapsamında görmektedir ${ }^{14}$. Madde metninde gerekçede olduğu gibi kaçınılabilir bir hatada cezanın indirilmesinin askıda bırakılması, herhangi bir sonuca bağlanmaması kanun metninin daha katı yorumlanmasına götürebilecek niteliktedir ${ }^{15}$. Alman öğretisinde güncelliğini yitirmiş ve ceza adaleti bakımından eleştirilen bu yorum $^{16}$ Türk Hukuk öğretisinde de benimsenmemiş, aşağıda da değinileceği üzere sınırlı kusur teorisi ya da unsur yanılgısı kapsamında çözümlenmesi gerektiği ifade edilmektedir ${ }^{17}$.

Sonuç olarak; birbirinden farklı kurumların aynı başlık altında toplanması, aynı hukuki sonucun doğmasını gerektirdiğinden, hata ile ilgili hükmün yorumlanmasında ve uygulamasında güçlüklere yol açacak niteliktedir ${ }^{18}$.

Söz konusu sonuç; hatanın kaçınılmaz olması halinde kişinin hatasından yararlanmasıdır. Hatanın kaçınılmaz olması halinde, hata hukuka uygunluk nedenine ilişkin ise, suç oluşmayacak, ceza sorumluluğunu kaldıran/azaltan nedenlere ait ise ceza verilmeyecek ya da azaltılacaktır ${ }^{19}$.

kez vursa kaçınılmaz bir hata içinde olduğu kabul edilebilirse A haksız tahrik hükmünden yararlanabilecektir. Ancak gerekli özeni gösterseydi gece de olsa yoldan geçenin C olduğunu fark edebilecek idiyse artık tahrikten yararlanamaz...(Veli Özer Özbek, Ceza Hukuku Dergisi, sayı 7, Türk Ceza Hukukunda Hata, s. 93. Kusurluluğu azaltan bir nedenin maddi koşullarında hataya düşülmüşse ( örneğin, haksız tahrik, ...m.29 ), kişi yanılgısı kaçınılmaz nitelikteyse bundan istifade eder ve ilgili kusurluluğu azaltan hâlden faydalanır. Bununla birlikte, hatası kaçınılabilir mahiyette ise, artık kusurluluğu azaltan sebepten faydalanamaz" ( M.E. Artuk-A. Gökcen-A.C. Yenidünya, Ceza Hukuku Genel Hükümler, 7. Bask1, s. 531.) şeklinde görüşlere yer verilmiştir....sanı̆̆ın bu hatasının kaçınılmaz nitelikte bir hata olmadı̆̆ı, sanığın TCK'nın 30. maddesinin 3. fikrasında düzenlenen ceza sorumluluğunu kaldıran veya azaltan nedenlere ait koşulların gerçekleştiği hususundaki hata hükmünden yararlanamayacağı kabul edilmelidir" şeklinde gerekçeyle Yargıtay CGK somut olayda kusurluluğu azaltan nedenlerdeki hatanın kaçınılmaz olmaması, yani kaçınılabilir olması durumunda hatadan yararlanamayacağı sonucuna varmıştır.

14 SCHÖNKE/SCHRÖDER, StGB § 16 Rn. 15; JOEKS, StGB § 16 Rn. 129.

15 Aynı yönde ÖZBEK/DOĞAN/BACAKSIZ, s.427.

16 SCHÖNKE/SCHRÖDER, StGB § 16 Rn. 15; ERMAN, s.310; TOPRAK, s.41.

17 ÖZGENÇ, (2006), s.421; KOCA/ÜZÜLMEZ, s.300; DEĞİRMENCİ, s.176; ERMAN, s.338.

18 GÜNGÖR, s.162; KEÇELİOĞLU,(2010), s.315 vd.

19 DEĞİRMENCI, s.162.

Ankara Hacı Bayram Veli Üniversitesi Hukuk Fakültesi Dergisi C. XXIV, Y. 2020, Sa. 3331 


\section{A. Hukuka Uygunluk Nedenlerinde Hata (m.30/3)}

Hukuka uygunluk nedenlerinde hata, bu nedenlerin koşullarında, varlığında veya kapsamında olmak üzere üç şekilde ortaya çıkabilmektedir. Ancak yukarıda da kısmen değindiğimiz üzere hukuka uygunluk nedenlerinde hatanın hukuki niteliğine ilişkin çıkarım, farklı hukuki sonuçlara gitmemize neden olmaktadir.

Hukuka uygunluk nedenleri Kanunda ayrı bölüm olarak değil, "Ceza Sorumluluğunu Kaldıran ve Azaltan Nedenler” başlığı altında düzenlenmiştir. $\mathrm{Bu}$ düzenleme hukuka uygunluk nedenlerinin hukuki niteliği konusundaki tereddütlerin yanı sıra, konunun temel noktası olan hukuka uygunluk nedenlerinin neler olduğu konusunda öğretide farklı görüşler doğmasına neden olmuştur. Hukuka uygunluk nedenlerinin sistematik yeri ve yer alan düzenlemenin semantik yorumu hukuka uygunluk nedenlerini tespit ederken referans noktası olarak kullanılmıştır ${ }^{20}$.

Öğretide, kanunun emrini icra (m.24/1), meşru savunma (m.25/1), hakkın kullanılması(m.26/1) ve ilgilinin rızasının (m.26/2) hukuka uygunluk nedenleri olduğu kabul edilmektedir. Buna karşın amirin emrini icra (m.24/2) ve zorunluluk halinin (m.26) hukuka uygunluk nedeni olup olmadığı ise tartışmalıdır. Bazı yazarlar bu iki nedeni "kusurluluğu kaldıran bir neden" olarak nitelendirirken", baz1 yazarlar "hukuka uygunluk nedeni" olarak nitelendirmektedir ${ }^{22}$.

Yargitay kararlarında da Ceza Muhakemesi Kanunda (m.223/3) "ceza verilmesine yer olmadığı" kararı verilmesini gerektirecek nedenler arasında sayılması dikkate alınmak suretiyle bu iki neden kusurluluğu ortadan kaldıran neden olarak kabul edilmektedir ${ }^{23}$.

20 DEĞİRMENCI, s. 165.

${ }^{21}$ KOCA/ÜZÜLMEZ, s.272 vd; ÖZGENÇ, (2006), s. 244; ARTUK/GÖKÇEN/ALŞAHİN/ ÇAKIR, s.567; AKBULUT, s.545, 574.

22 CENTEL/ZAFER/ÇAKMUT, s.293; DEMIRBAŞ, s.276, 296; ÖZTÜRK/ERDEM, s.260 vd.

23 Y.13. CD, 11.11.2014, E.2014/9942, K.2014/31481. "Olay günü çok sayıda kişinin karıştığ1 kavgada bıçakla yaralanan arkadaşı İ.'ı hastaneye yetiştirmek amacıyla ekip aracını çalan sanığın arkadaşını hastaneye götürdüğ̈̈, aracın da kolluk kuvvetleri tarafindan hemen acil servis önünde bulunduğunun anlaşılması karsısında, sanığın eyleminin TCK'nın 147. maddesinde düzenlenen "zorunluluk hali" kapsamında kaldığı, bu nedenle sanık hakkında CMK'nın 223/3-b bendi uyarınca ceza verilmesine yer olmadı̆̆ına şeklinde karar verilmesi gerekirken, hukuka uygunluk nedeni bulunduğundan bahisle yazılt şekilde 
Ceza sorumluluğuna etkisinin tespitinde hukuki nitelendirmenin mutlak belirleyici bir ölçüt olduğu şüphe dışında olmakla birlikte, makalenin konusu ve kapsamı itibariyle hukuka uygunluk nedenlerinin tahdidi tasnifi ayrıntılı bir analizi gerektirdiğinden, makalemizin sınırlı çerçevesinin dışında tutulmuştur.

Hukuka uygunluk nedenlerinin Türk Ceza Kanunu'nun genel hükümlerdeki düzenlemelerinden ibaret olmadığını belirtmekte fayda görmekteyiz.

Hukuka uygunluk sebepleri Ceza Kanunu dışında bir kanundan kaynaklanabileceği gibi, bir davranışa idare hukuku ya da özel hukuk alanında da izin verilmiş olabilir. Hukuk düzeninin bütünlüğü ve ihlal edilmezliği ilkesi uyarınca Ceza Kanunu dışında düzenlenmiş olması, hukuki niteliğini değiştirmez ve bu söz konusu davranış Ceza Kanununca yasaklanamaz ${ }^{24}$.

Hukuka uygunluk nedenlerinde hata, maddi koşullarında, varlığında ya da sinırlarında olabilmektedir. Bir hukuka uygunluk nedeninin aynı unsur hatasında olduğu gibi koşulları hatalı kabul edilebilir veya hukuk düzeninde mevcut olmayan bir hukuka uygunluk nedeni var zannedilebilir ya da hukuka uygunluk sebebinin sinırında hata yapılabilir25

Hukuka uygunluk nedenlerinin maddi koşullarında hata ${ }^{26}$ halinde, failin hatas1, maddi bir hususa dairdir ${ }^{27}$. Bu bakımdan, unsur hatası ile ortak bir noktaya sahiptir. Her iki hata türünde de, fail için geçerli olan hukuk normlarına değil, maddi vakıalara ilişkin bir yanılma söz konusudur ${ }^{28}$.

Alman Ceza Hukukunda öğretideki ağırlıklı görüşe göre hukuka uygunluk nedenlerinin maddi koşullarında hata durumunda yapısal ve nesnel anlamda suçun maddi koşullarında hatayla ${ }^{29}$ örtüştügünden sınırlı

beraat kararı verilmiş olması bozmayı gerektirmiş, katılan vekilinin temyiz istemi bu bakımdan yerinde görülmüş olduğundan, hükmün açıklanan nedenle tebliğnameye aykırı olarak BOZULMASINA” ; ayn1 yönde Y.15.CD, 4.11.2015, E.2015/7261, K.2015/30817.

24 JÜNEMANN, s. 279 vd.(Çeviren İlker Tepe); aynı yönde DEĞİRMENCİ, s.165.

25 KOCA, s.94.

26 Erlaubnistatbestandsirrtum;Erlaubnissachverhaltsirrtum;Erlaubnistatumstandsirrtum.

Öğretide "Erlaubnissachverhaltsirrtum" kavramının en doğru nitelemeye sahip olduğu, burada hukuka uygunluk koşullarına ilişkin bir olgunun (Sachverhalt) tasavvur edildiği ifade edilmektedir. (BOCK, s.370)

27 HÖFLICH/WELLER s.97; FREUND, s.291-292; HEINRICH, 175; GROPP, s.478- 479.

28 PUPPE, StGB § 16, Rn.156; ERMAN, s.277.

29 Tatbestansirrtum

Ankara Hacı Bayram Veli Üniversitesi Hukuk Fakültesi Dergisi C. XXIV, Y. 2020, Sa. 3333 
kusur teorisi ${ }^{30}$ çerçevesinde aynı hüküm (Alman Ceza Kanunu m.16 I) uygulanmaktadır ${ }^{31}$. Bu görüşün temelini failin hukuka aykırılık kastının ${ }^{32}$ bulunmaması oluşturmaktadır ${ }^{33}$. Fail maddi koşullarda yanıldığı zaman, aslında hukuk düzenine bağlı kalmaktadır. Diğer taraftan Alman Ceza Kanunu m.16 I maddesinin sadece unsur hatalarında uygulanacağına dair bir sınırlama getirilmemiştir. Ayrıca yapılan kıyasın failin lehine olması nedeniyle de hukuk düzeniyle çelişmeyeceği vurgulanmaktadır ${ }^{34}$.

Hukuka uygunluk nedeninin varlığı veya sinırları konusunda hataya düşülmesi ise Alman öğretisinde izin hatas $1^{35}$ olarak nitelendirilmektedir. Burada hata halinde fail, hukuka uygunluk nedenini mevcut zannetmekte ya da sınırlarını olduğundan geniş kabul ederek, hareketini gerçekleştirmektedir ${ }^{36}$.

İzin hatasının, Alman öğretisinde ağırlıklı görüşe göre Alman Ceza Kanunu'nun 17. maddesi kapsamında yasak hatası olarak değerlendirilmesi gerektiği belirtilmektedir ${ }^{37}$. İzin hatası, hukuki değerlendirme hatası olarak kabul edilmektedir. Dolayısıyla kasıtla değil, haksızlık bilinci ile ilintili olduğu ve bu nedenle kusurluluğu ortadan kaldıran bir durum olarak değerlendirmesi gerektiği ifade edilmektedir.

$\mathrm{Bu}$ kabulden hareketle ceza sorumluluğun kalkması için, failin hatasının kaçınılmaz olması şarttır ${ }^{38}$. Aksi durumda, yani hatanın kaçınılabilir olması durumunda ise Alman Ceza Kanunu'nun 49/1.maddesinde düzenlenen ve kanunun cevaz verdiği durumlarda indirimin esaslarını düzenleyen hükmü gereğince ihtiyari bir ceza indirimi söz konusu olacaktır ${ }^{39}$.

\footnotetext{
$30 \quad$ Eingeschränkte Schuldtheorie

31 KINDHAUSER/NEUMANN/PAEFFGEN, StGB § 16, Rn. 137; JOEKS, StGB § 16 Rn.127; HÖFLICH/WELLER, s.97; SCHÖNKE/SCHRÖDER, StGB § 16 Rn.16-18.

BGHSt 3, 105 (106ff); 194 (196); BGH NStZ 2001, 530 (531); 2004, 204 (205); NStZ-RR 2002, 37 .

32 Vorsatzunrecht

33 KINDHAUSER/NEUMANN/PAEFFGEN, StGB § 16, Rn. 137.

34 HEINRICH, s. 183

35 Erlaubnisirrtrum

36 HEINRICH, s.194.

37 HÖFLICH/WELLER, s.97.

38 HEINRICH, s.195-196.

39 HÖFLICH/WELLER, s.97.
}

334 Ankara Hacı Bayram Veli Üniversitesi Hukuk Fakültesi Dergisi C. XXIV, Y. 2020, Sa. 3 


\section{aa. Hukuka Uygunluk Nedenlerinin Varlığında Yanılma}

Fail, gerçekte hukuk düzeninin kabul etmediği bir hukuka uygunluk nedeninin var olduğunu sanarak hareket etmektedir. Burada hukuka uygunluk nedeninin maddi koşullarında bir yanılma söz konusu olmayıp, fail hukuka uygunluk nedeninin varlığ konusunda ya da sinırlarında yanılgı içindedir. Failin hukuken geçerli olmayan bir rıza açıklamasını geçerli telakki etmesi durumunda izin normunun varlığında hata söz konusudur ${ }^{40}$. Mesleğe yeni başlayan bir doktorun ötanazinin Türk Hukuk sisteminde bir hukuka uygunluk nedeni olduğu düşüncesi ile amansız bir hastalığa yakalanan hastasının yaşam desteğini sona erdirmesi izin normunda yanılmaya, tedip hakkının etkili eylemde bulunma hakkını verdiğini düşünen ebeveynin bu yöndeki davranışı, izin normunun sınırlarında yanılmaya örnek gösterilebilir ${ }^{41}$.

"Hukuka uygunluk nedenlerinin varlığında yanılma", sınırın aşılması şeklinde tezahür eden "hukuka uygunluk nedenlerinin sınırı konusunda yanılma" ile birlikte aslında yürürlükte bulunan hukuk normlarının bilinmemesine ya da sınırlarının yanlış bilinmesine dayanmaktadır. Fail burada izin normu olduğunu sanarak ya da izin normunun sınırını daha geniş yorumladığı için yanılgı içindedir.

Alman ve Türk Ceza Kanunlarında düzenlenmemiş bulunan ve "dolaylı" ya da "somut"43 yasak yanılgısı olarak nitelenen bu yanılg1 şeklinde; yasak yanılgısından farklı olarak fail hareketinin suç oluşturduğunu bilmekte, ancak hukuka uygunluk nedeninin varlığı nedeniyle eyleminin hukuka aykırı olmaktan çıktığını düşünmektedir ${ }^{44}$.

Uygulamada hukuka uygunluk nedenlerinin maddi koşullarında hata ile izin hatası karıştırılabilmektedir. Öncelikle unsur hatasında olduğu gibi, hukuka uygunluk nedeninin maddi koşullarının betimleyici ya da normatif unsurlarına ilişkin olabilmektedir. Salt hukuka uygunluk nedeninin normatif unsuruna ilişkin olduğu için yasak hatası olarak nitelendirilmesi mümkün değildir ${ }^{45}$.

\footnotetext{
40 KINDHAUSER/NEUMANN/PAEFFGEN, StGB § 228, Rn. 113-115.

41 DEĞİRMENCİ, s.168.

42 Indirekter Verbotsirrtum; JOEKS, StGB § 17, Rn.32-33; HEINRICH, s.195; FREUND, s.291.

43 KOCA, s.95; HEINRICH, Kn.1142, KOCA/ ÜZÜLMEZ, s.367.

44 JOEKS, StGB § 17, Rn.33; TOPRAK, s.43-44.

45 ERMAN, s.282.
} 
Burada izin normunda $\mathrm{m} 1$, yoksa maddi koşullarında $\mathrm{m}$ 1 hataya düşüldügünün tespiti için, failin hatasının maddi koşullardaki bilgisizlikten kaynaklanıp kaynaklanmadığının tespiti gerekmektedir. Failin hukuka uygunluk nedenlerinin maddi koşullarında yanıldı̆̆ının söylenebilmesi için maddi vakıaların tasavvurunda yanılgıya düşmesi gerekmektedir. Fail tüm maddi vakıaları bilmesine karşın, normun değerlendirilmesinde hataya düşmüş ise, bu sefer de izin normunda hataya düştüğünün kabul edilmesi gerekmektedir ${ }^{46}$.

İzin normunun varlığında ya da sınırında yanılmanın hukuksal niteliğinin ne olduğu, bir başka deyişle ceza sorumluluğu bakımından nasıl sonuç doğuracağı konusu öğretide ayrı bir tartışma konusudur.

Alman öğretisinde; izin normunda hata, yasak yanılgisı kapsamında değerlendirilmekte (Alman Ceza Kanunu m.17), ${ }^{47}$ hukuki değerlendirme alanında kalan bir hata olarak nitelendirilmektedir. Burada unsur hatasını düzenleyen 16. maddenin aksine failin kasıtlı davranıp davranmadığı tartışma konusu yapılmamaktadır ${ }^{48}$.

Ayrıca Alman Öğretisinde failin eyleminin haksızlık oluşturduğu hususundaki hatalı tasavvur ile (yasak hatası) hukuk düzeninin bu eylemi hukuka uygun gördügüne ilişkin tasavvur arasında (izin hatası) herhangi bir fark bulunmadığ 1 görüşü hâkimdir ${ }^{49}$. Bu konuda öğretide ve uygulamada herhangi bir görüş ayrılı̆ğ da bulunmamaktadır ${ }^{50}$.

Alman Ceza Hukuku uygulamasında, failin hatasının kaçınılmaz olması halinde fail kusurlu addedilemeyecek ve ceza sorumluluğu ortadan kalkacaktır. Aksi durum, yani hatanın kaçınılabilir olması durumunda ise, kusur varlığını devam ettirmektedir. Bu durumda ancak Alman Ceza Kanunu'nun 49/1. maddesi uyarınca ihtiyari bir ceza indirimi söz konusu olabilmektedir ${ }^{51}$.

Türk Ceza Kanunu'nun 30/3. Maddesindeki düzenleme incelendiğinde ise; hatanın hukuki niteliğinden bahsedilmediği, kaçınılmaz hata halinde,

\footnotetext{
46 PUPPE, StGB § 16, Rn.142, 143; ERMAN, s. 285.

47 KINDHAUSER/NEUMANN/PAEFFGEN, StGB $\S 228$, Rn. 113-115; FISCHER, StGB § 17, Rn.11a; KÜHL, StGB § 17, Rn.19; GROPP, s.486.

48 TOPRAK, s.45.

49 KÜHL, StGB § 17, Rn.19; PUPPE, s.141; ERMAN, s.281.

50 ERMAN, s.281.

51 HEINRICH, s.196.
} 
failin bu hatasından istifade edeceğinin belirtildiği görülmektedir. Maddedeki düzenlemeden kaçınılmaz hatanın varlığı halinde kusurluluğun ne şekilde etkilendiği anlaşılmamaktadır. Kaçınılabilir yanılgı durumunda da ceza sorumluluğunun ne şekilde yorumlanması gerektiği metinde bu konuda bir hüküm bulunmadığından izaha muhtaçtır.

Bazı yazarlar düzenlenen unsur hatası (tipte hata) hükümlerinin uygulanmas1 suretiyle, bu durumda failin kastının ortadan kalkmas1 gerektiğini ifade etmektedirler. $\mathrm{Bu}$ yazarlara göre suçun taksirli halinin mevcut olması durumunda da fail taksirli eylemden sorumlu olacaktır ${ }^{52}$. Zira "kaçınılabilirlik" kavramı özensizlik ve dolayısıyla taksirle bağlantılı bir davranış olarak nitelendirilmektedir. Eylemin taksirli şeklinin cezalandırıldığ suçlardan olması durumunda meydana gelen neticeden failin taksiri nedeniyle cezalandırılması gerektiği görüşü ileri sürülmektedir ${ }^{53}$. Sorumluluğun taksir kapsamında değerlendirilmesi gerektiği savunulmakla birlikte, bu konuda tereddütlerin giderilmesi bakımından açık bir hüküm konulmasında yarar olduğu ifade edilmektedir ${ }^{54}$.

Kaçınılabilirlik kavram1 ${ }^{55}$ taksirle benzerlik göstermekle birlikte, taksir tipik $^{56}$ haksızlığın manevi (sübjektif) unsurunu oluşturmaktadır. Kanunu'nun taksir, "dikkat ve özen yükümlülüğ̈̈ne aykırılık dolayısıyla, bir davranışın suçun kanuni tanımında belirtilen neticesi öngörülmeyerek gerçekleştirilmesi olarak" tanımlanmaktadır (m.22). Taksir tipik haksızlığın bir unsuru olarak görülmektedir.

Haksızlık yanılgısının ve dolayısıyla hukuka uygunluk nedenlerinin varlığında hatanın kaçınılabilirliğine ilişkin ise herhangi bir ölçüt getirilmediği görülmektedir. Alman öğretisinde potansiyel haksızlık bilinciyle, yani failin davranışının hukuka aykırı olduğu bilgisine ulaşma yeteneği ile özdeş olarak nitelendirilmektedir ${ }^{57}$. Alman Federal Mahkemesi’nin kabul ettiği ölçütlere göre ise, "olayın koşulları, failin kişiliği, yaşantısı ve mesleki çevresi dikkate alındiğında kendisinden beklenen vicdan gerilimine karşın, davranışının haksızlık oluşturduğu bilincini kazanabilecek durumda bulunmuyorsa"

\footnotetext{
52 HAKERİ, s.460; ÖZBEK/DOĞAN/BACAKSIZ, s.427.

53 HAKERİ, s.460; ÖZBEK/DOĞAN/BACAKSIZ, s.427.

54 HAKERİ, s.460.

55 Vermeidbarkeit

56 Fahrlässigkeit

57 ERMAN, s. 226.
} 
düştüğü haksızlık yanılgısının kaçınılmaz olduğu kabul edilmektedir ${ }^{58}$. Vicdan gerilimi ${ }^{59}$ ölçütünü kullanan Federal Mahkeme, kendisinden beklenen vicdan muhasebesine girişmesine karşın eylemin hukuka aykırılığına ilişkin bir görüşe ulaşamayan kişinin hatasını kaçınılmaz olarak kabul etmektedir ${ }^{60}$.

Failin somut olayda tipe uygun davranışının aynı zamanda hukuka aykırı olup olmadığını araştırmasında özel bir özen göstermesi gerekmektedir. Burada sorun, fiilin haksızlığına ilişkin değil, failin kişisel olarak hataya düşmedeki kusurunun değerlendirilmesi ile ilgilidir. Bir başka deyişle burada failin zihnindeki düşünsel süreç araştırılmaktadır ${ }^{61}$. Failin yaşı, mesleki eğitimi ve tecrübesi, sosyal yaşam içindeki konumu ve somut olaydaki durumu dikkate alınarak hatanın kaçınılabilir olup olmadığı değerlendirilecektir ${ }^{62}$.

Alman Öğretisi ve Federal Mahkemesi Kararlarında dikkat ve özen yükümlülüğü kaçınılabilirdik kavramının ölçütlerinden biri olarak görülmekte, somut olayda dikkat ve özen yükümlülüğünün kusur prensipleri çerçevesinde failin kişisel özelikleri dikkate alınarak değerlendirilmesi gerektiği belirtilmektedir ${ }^{63}$. Bu çerçevede failin somut yaşam koşulları ve mesleki çevresi dikkate alınmaktadır ${ }^{64}$.

$\mathrm{Bu}$ değerlendirmenin fail ile hukuk normu arasında bir değerlendirme olduğu, dolayısıyla tipik haksızlığın dışında olduğu açık olmakla birlikte, Türk Ceza Hukuku öğretisinde Alman Hukukuna benzer şekilde yanılgının kaçınılabilirliği noktasında, taksirli suçlar bakımından söz konusu olan özen yükümlülüğünün ihlaline ilişkin ölçütlerin kullanılması gerektiği belirtilmektedir ${ }^{65}$.

Yargıtay kararlarında kaçınılmazlık hâli takdir edilirken, failin gereken dikkat ve özeni göstermesi yönünden yapılan bir değerlendirme ile sonuca varılmaktadır. Dikkat ve özenin gösterilmesinde failin kişisel özellikleri de

\footnotetext{
58 BGH, 27.01.1966, KRB 2/65 say1l Karar1, BGHst 21, s.18 vd., s.21.

59 Die Anspannung des Gewissens

60 BGH, 18.03. 1952, GSSt 2/51 say1l1 Karar1, BGHSt, 2, s.194 vd., s.201; SCHÖNKE/ SCHRÖDER, StGB § 17 Rn. 14-15.

${ }^{61}$ GÖKTÜRK, (2016), s.149.

${ }^{62}$ KOCA/ÜZÜLMEZ, s. 369; GÖKTÜRK, (2016), s.149; SOYER GÜLEÇ, s.80 vd.

63 SCHÖNKE/SCHRÖDER, StGB § 17 Rn. 17. BGH 3366.

${ }^{64}$ Frankfurt NJW 64, 508; BGH DAR 66, 189, BGH 40264.

65 ÖZGENÇ, (2019), s.483; ÖZGENÇ, (2006), s.425.
} 
dikkate alınmaktadır ${ }^{66}$. Hatanın kaçınılmaz olduğunun tespitinde failin kişilik özellikleri kapsamında bilgi düzeyi, gördüğü eğitim, içerisinde bulunduğu sosyal ve kültürel çevre şartları göz önünde bulundurulmaktadır ${ }^{67}$.

GÖKTÜRK ise, aralarında özen yükümlülüğünün gösterilmesi bakımından benzerlik olduğunu kabul etmekle birlikte, bu yükümlülüğün konu, kapsam ve içeriğinin tamamen farklılık gösterdiğini belirtmektedir ${ }^{68}$.

Kaçınılabilirlik değerlendirmesinin failin bilinci ile ilgili olmas1 nedeniyle kusur yeteneği ile doğrudan bağlantılı olduğu konusunda tereddüt bulunmamaktadır. Dolayısıyla kusur yeteneğini ortadan kaldıran

66 YCGK, 13.2.2018, E.2017/1-183, K.2018/33. “5237 Say1lı TCK'nun 30. maddesinin üçüncü fikrasında "Ceza sorumluluğunu kaldıran veya azaltan nedenlere ait koşulların gerçekleştiği hususunda kaçınılmaz bir hataya düşen kişi, bu hatasından yararlanır" hükmü yer almaktadır. Fıkrada hem hukuka uygunluk sebebinin maddi şartlarında hata, hem de kusurluluğu etkileyen hata hâlleri düzenlenmiştir. Hatanın kaçınılmaz olması halinde, fail bu hatasından yararlanacaktır. Kaçınılmazlık hâli takdir edilirken, failin gereken dikkat ve özeni göstermesi durumunda bu hataya düşüp düşmeyeceği belirlenmelidir.

Ceza sorumluluğunu kaldıran meşru savunma ile azaltan nedenlerden olan haksız tahrikin varlığı konusunda da hataya düşülebilir. Meşru savunma koşullarının veya haksız tahrikin varlığ 1 konusunda kaçınılmaz hataya düşen fail bu hükümlerden yararlanacaktır. Fakat burada hatanın kaçınılmaz olması zorunludur. Buna karşılık, hata kaçınılabilir bir hata ise, yani failin kişisel özellikleri göz önüne alındı̆̆ında, daha dikkatli ve özenli davranması durumunda hatasından kaçınılabilecekse başka bir anlatımla hata meydana gelmeyecekse artık meşru savunma veya haksız tahrik hükümlerinden yararlanamayacaktır”.

67 YCGK, 7.11.2019, E.2018/1-27, K.2019/644. "Üçüncü fikrada ceza sorumluluğunu kaldıran ya da azaltan nedenlere ait şartların gerçekleştiği konusunda kaçınılmaz bir hataya düşen kişinin, bu hatasından yararlanacağı hüküm altına alınmış, fikrada hem hukuka uygunluk sebebinin maddi şartlarında hata, hem de kusurluluğu etkileyen hata hâlleri düzenlenmiştir. Failin bu hükümden yararlanabilmesi için, içerisinde bulunduğu şartlar bakımından hatasının kaçınılmaz olması gerekmektedir.

5377 Sayılı Kanun ile eklenen dördüncü fikrada ise, kişinin işlediği fiilden dolayı kusurlu ve sorumlu tutulabilmesi için, bu fiilin bir haksızlık oluşturduğunu bilmesi gerektiği vurgulanmıştır. Buna göre fail, işlediği fiilin haksızlık oluşturduğu konusunda kaçınılmaz bir hataya düşmüş, diğer bir ifadeyle eyleminin hukuka aykırı olmadığı, haksızlık oluşturmadığ 1 , meşru olduğu düşüncesiyle hareket etmiş ve bu yanılgısı içinde bulunduğu şartlar bakımından kaçınılmaz nitelikte bulunmuş ise artık cezalandırılmayacaktır. Hatanın kaçınılmaz olduğunun tespitinde kişinin bilgi düzeyi, gördü̆̈̈̈ eğitim, içerisinde bulunduğu sosyal ve kültü̈rel çevre şartları göz önünde bulundurulacaktır.

Üçüncü ve dördüncü fikraların uygulanması yönüyle kişinin kaçınılmaz bir hataya düşmesi şartı aranmakta olup, hatanın kaçınılabilir olması durumunda kişi kusurlu sayılacak, diğer bir ifadeyle fiilinden dolayı sorumlu tutulacak, ancak bu hata temel cezanın tayininde dikkate alınacaktır."

68 GÖKTÜRK, (2016), s.149 vd; ERMAN, s.239 vd; Kaçınılabilirlik olgusunun koşulları ve sınırları ile ilgili ayrıntılı inceleme için bkz. SCHÖNKE/SCHRÖDER, StGB § 17 Rn. 13 vd.; GÖKTÜRK, (2016), s.149 vd; ERMAN, s.239 vd. 
ya da etkileyen durumlar ön koşul olarak değerlendirilebilecek, böyle bir durumda haksızlık bilincinin de ortadan kalkacağ 1 ya da azalacağı sonucuna varılabilecektir.

Diğer taraftan failin kusur yeteneğinin irdelenmesini gerektiren ölçütler bakımından kaçınılabilirlik olgusu ile taksir sorumluluğu karşılaştırıldığında, taksir sorumluluğunun tespitinde Kanun'un hangi görüşü esas aldığının da dikkate alınması gerekmektedir. Failin sadece kişisel yeteneği dikkate alınarak, gösterebileceği özeni ölçüt kabul eden ve bu kapsamda failin kişisel yeteneğini esas alan sübjektif teori (kişisel kaçınılabilirlik teorisi) haksızlık yanılgısında kaçınabilirdik ölçütleri ile büyük ölçüde örtüşmekle birlikte, öğretide azınlıkta kalan bir görüştür ${ }^{69}$.

5237 sayllı Kanun'un taksire ilişkin 22. madde gerekçesinde; dikkat ve özen yükümlülügünün belirlenmesinde, failin kişisel yetenekleri göz önünde bulundurulmaksızın, objektif esastan hareket edilmesi gerektiği belirtilmiştir. Objektif teoride dikkat ve özen yükümlülüğü değerlendirilirken ex-ante, tedbirli, bilinçli ve ortalama bir insanın tercih edeceği davranış dikkate alınmaktadır ${ }^{70}$.

Özen yükümlügünün belirlenmesinde objektif ölçü esas olmakla birlikte, failin kişisel özelliklerinin dikkate alınması gerektiği öğretide savunulmaktadır ${ }^{71}$. Örneğin bir doktorun çok özel bir alandaki ihtisası, dikkat ve özen yükümlüğünün bu konuda özel bir ihtisası olmayan diğer bir doktordan daha farklı değerlendirilmesini gerektirecektir ${ }^{72}$.

Kaçınılabilirlik olgusunun taksirden farklı olarak kusur yeteneği ile ilişkisi ve kusur yeteneği yönünden değerlendirmeyi gerektirmesi dikkate alındığında, bu olguya ilişkin özen yükümlülüğünün kendine özgü bir içeriği olduğu anlaşılmaktadır. Bu nedenlerle kaçınılabilirlik değerlendirmesinde taksire ilişkin ölçütlerden faydalanılabilecek olmakla birlikte, bu ölçütlerin tek başına yeterli olmayacağını düşünmekteyiz.

Kaçınılmaz bir hata söz konusu olduğunda, ya da tam aksi şekilde hatanın kaçınılabilir olması durumunda hukuki sorumluluğun ne şekilde oluşacağ1 konunun en önemli sorusunu oluşturmaktadır. Lakin 5237 sayılı Kanun’un

\footnotetext{
69 KOCA/ÜZÜLMEZ, s.204.

70 KOCA/ÜZÜLMEZ, s.205.

71 KOCA/ÜZÜLMEZ, s.205.

72 KOCA/ÜZÜLMEZ, s.205.
} 
30/4. maddesi yukarıda da belirttiğimiz üzere kaçınılmaz hata konusunda yeterli açıklığa sahip değildir. Kaçınılabilir bir hataya ilişkin ise Kanunda herhangi bir hüküm öngörülmüş değildir.

İzin normunun varlığında ya da sınırında yanılma durumunda maddi vakıanın failin zihninde yanlış tasavvuru şeklinde bir durumun söz konusu olmadığı düşüncesi hâkimdir. Aksine, fail maddi vakıayı zihninde doğru bir şekilde tasavvur etmekte, ancak eylemine hukuk düzeninin izin verdiği konusunda yanılgıya düşmektedir. Fail suç tipine dayanak oluşturan normda değil, ancak normun yasakladığ 1 davranışa izin veren normda hata yapmaktadır. Yanılg1 norma dayalı olup, kasitla ve de unsur hatası ile bir ilgisi bulunmamaktadır ${ }^{73}$.

$\mathrm{Bu}$ nedenle kanaatimizce faile haksızlık yanılgıs1 (m.30/4) hükümleri kıyasen uygulanmalıdır. İşlediği fiile hukuk düzeninin izin verdiği konusunda kaçınılmaz bir hata içinde bulunması halinde failin kusuru tamamen ortadan kalkacağ 1 için faile ceza verilmez.

İzin yanılgısının kaçınılabilir olması durumunda herhangi bir ceza indiriminin öngörülmemiş olması kusur ilkesiyle bağdaşmamaktadır. Failin hatasının kaçınılabilir olması kusurunun azalması anlamına geldiğinden, kusuru oranında cezalandırılmasına imkân veren bir düzenlemeye yer verilmesi gerektiği düşünülmektedir. Madde gerekçesinde "kaçınılabilir hata durumunda kişinin kusurlu sayllacağl ve bu hususun temel cezanın belirlenmesinde göz önünde bulundurulacă̆g" şeklindeki 61. maddeye yapılan atfin ise amaca elverişli olmadığ 1 düşüncesindeyiz ${ }^{74}$. Zira m.30/3'deki düzenlemede Alman Ceza Kanunu'nun 17/2. maddesindeki gibi indirim halini düzenleyen bir hükme yer verilmemiştir. Gerekçeyi esas alarak "kaçınılabilir" hata hallerinde ceza indirimi uygulamanın kanunilik ilkesiyle ne derece bağdaşabileceği tartışmalıdır ${ }^{75}$.

Failin gerekli dikkat ve özeni göstermesi durumunda yanılgıya düşmeyeceği sonucuna varılıyor ise, kaçınılabilirliğin ölçüsüne göre kusurundaki azalma oranında kasten işlenen suçun cezasında indirim yapılması gerekir $^{76}$. Kaçınılabilirliğin derecesine göre kusurun derecelendirilebilmesi

\footnotetext{
73 GÖKTÜRK, (2014), s.28; DEĞİRMENCİ, s.170.

74 Aynı yönde GÖKTÜRK, (2016), s.143 vd.

75 OZANSÜ, s.395.

76 ÖZGENÇ, (2019), s.488; GÖKTÜRK, (2014), s.30; Kaçınılabilirlik kavramı hakkında
} 
mümkün k1lan bir düzenlemenin olması, uygulamada doğabilecek tereddütleri giderebilecektir.

Yargıtay içtihatlarında da hatanın kaçınılabilir olması durumunda kişi kusurlu kabul edilmekte ve fiilinden dolayı sorumlu tutulmakta, ancak bu hata temel cezanın tayininde dikkate alınmaktadır ${ }^{77}$.

\section{bb.Hukuka Uygunluk Nedenlerinin Maddi Koşullarında Hata ${ }^{78}$}

Failin hukuka uygunluk nedeninin koşullarının somut bir olayda gerçekleştiğini düşünmesi olarak tanımlanmaktadır ${ }^{79}$. Fail yanılmamış olsa idi, fiili hukuka aykırı olmayacaktı. Fail maddi durumun mevcudiyeti konusunda yanılmakta, aslında var olmayan bir hukuka uygunluk nedenine ilişkin koşulları var zannetmektedir.

Örneğin A, caddede yürürken B'nin C'ye silah doğrulttuğunu görür ve C'ye yardım etme kastıyla B'ye ateş eder ve ağır şekilde yaralanmasına neden olur. Aslında bir dizinin çekimi yapılmaktadır ve A kamera ekibini görmemiştir. Bu örnekte de görüleceği üzere A tamamıyla hukuka uygunluk nedenin koşullarında yanılmaktadır ${ }^{80}$.

Failin hukuka uygunluk nedeninin maddi koşullarını bilmemesi, yani maddi koşullarda yanılgıya düşmesi durumunda hukuki sorumluluğunun ne olacağı konusunda farklı görüşler bulunmaktadır.

5237 say1l Kanunun 30/3. maddesinde, “ceza sorumluluğunu kaldıran ya da azaltan nedenlere ait koşulların gerçekleştiği konusunda kaçınılmaz bir hataya düşen kişi, bu hatasından yararlanır.” hükmüne yer verilmiştir. Düzenlemedeki koşullar ifadesi ile "maddi koşulların” kastedildiği konusunda

ayrıntılı bilgi için bkz. SCHÖNKE/SCHRÖDER, StGB § 17 Rn. 13 vd; GÖKTÜRK, (2016), s. 143 vd.; ERMAN, s.239 vd.

77 YCGK, 7.11.2019, E.2018/1-27, K.2019/644; YCGK, 13.2.2018, E.2017/1-183, K.2018/33.” ...Üçüncü ve dördüncü fikraların uygulanması yönüyle kişinin kaçınılmaz bir hataya düşmesi şartı aranmakta olup, hatanın kaçınılabilir olması durumunda kişi kusurlu sayılacak, diğer bir ifadeyle fiilinden dolayı sorumlu tutulacak, ancak bu hata temel cezanın tayininde dikkate alınacaktır".

78 Erlaubnistatbestandsirrtum; Erlaubnissachverhaltsirrtum. Alman Hukukunda izin tipinde yanılma (Erlaubnistatbestandsirrtum), ya da izinde maddi vakıa yanılgıs1 (Erlaubnissachverhaltsirrtum) kavramları kullanılmaktadır (FREUND, s.291).

79 ERMAN, s.277; ÖZBEK/DOĞAN/BACAKSIZ, s.426.

80 HÖFLICH/WELLER, 97. 
bir tereddüt bulunmamaktadır ${ }^{81}$. Dolayısıyla konu normatif bir düzenlemeye sahip olmakla birlikte, sorun hukuka uygunluk nedenlerinin maddi koşullarında hatanın m.30/3 gereğince çözümünün ne derece doğru sonuçlar doğurduğudur.

Hukuka uygunluk nedenlerinde hataya ilişkin Alman Hukukundaki teorik tartışmalar kabul edilen teoriye göre bizi farklı ya da aynı hukuki sonuca götürmektedir.

Alman öğretisinde katı kusur teorisi, maddi koşullarda hatayı suçun yasal tanımında yer alan unsurlarla sinırlı tutmakta, yasal unsurların dışında görülen hukuka aykırılık nedenleri ise yasak hatası içinde değerlendirilmektedir. Dolayısıyla hukuka uygunluk nedenleri kastın kapsamı içinde değerlendirilmemekte ve bu nedenle bu koşullardaki hata kastı ortadan kaldırmamaktadır ${ }^{82}$.

Katı kusur teorisi hukuka uygunluk nedenlerinin maddi koşullarında hatanın haksızlık yanılgısını düzenleyen Alman Ceza Kanunu'nun 17. maddesine göre belirlenmesini savunmaktadir ${ }^{83}$. Failin fiilini kasten gerçekleştirdiğinden kabulle bir yandan çok geniş bir cezalandırmaya cevaz vermesi, diğer taraftan ise ceza politikası ile bağdaşmaması ve olası cezalandırma boşlukları doğabileceği gerekçeleriyle eleştirilmektedir ${ }^{84}$. Ayrıca yasaklayıcı normda değil, maddi vakıada yanılan failin durumunun 17.madde kapsamında görülmesinin doğru olmadığ 1 ifade edilmektedir ${ }^{85}$.

TCK'daki düzenlemede (m.30/3) haksızlık yanılgısına ilişkin hükme benzer bir düzenlemeye yer verildiği dikkate alındığında, Kanunumuzda katı kusur teorisinin esas alındığı düşüncesini doğurmaktadır. Hukuka uygunluk nedenlerinin koşullarında hata ile nedenlerin varlığında ve sınırlarının aşılmasında hata hallerinin aynı maddede düzenlenmesi, dolayısıyla aynı hukuki sonuca bağlanması bu görüşü pekiştirmektedir. Diğer taraftan madde gerekçesi de bu görüşü doğrular niteliktedir. Gerekçeye göre, "hatanın kaçınılabilir olması durumunda, kişi işlediğifiilden dolayı sorumlu tutulacak ve fakat bu hata, temel cezanın belirlenmesinde göz önünde bulundurulacaktır."

\footnotetext{
81 GÖKTÜRK, (2014), s.26.

82 KINDHAUSER/NEUMANN/PAEFFGEN, StGB § 16, Rn. 127-128; KÜHL, Art 17, Rn.9; ÖZGENÇ, (2019), s.478; ARTUK/GÖKÇEN/ALŞAHIN/ÇAKIR, s.647-648; ERMAN, s.303.

83 BOCK, s.371.

${ }^{84}$ BOCK, s371; SCHÖNKE/SCHRÖDER, StGB § 16 Rn. 15.

85 BOCK, s.371.
} 
Öğretide de Kanundaki düzenlemenin "katı kusur teorisi" olarak nitelenen görüşe göre formüle edildiği ifade edilmektedir ${ }^{86}$.

Ancak hukuka uygunluk nedenlerinin koşullarında yanılmanın, suçun maddi unsurlarında yanılma ile benzer özellikler göstermesine karşın, çok daha katı ölçütler ve sonuçlar doğuran haksızlık yanılgısı ile bir tutulması adaletsiz olarak nitelendirilmektedir ${ }^{87}$.

Yukarıda da belirttiğimizüzere, yasak (haksızlık) yanılgısına ilişkinAlman Ceza Kanunundaki kaçınılabilir yasak yanılgısında indirim öngören hükme TCK'da yer verilmemiştir. Ayrıca taksirli hallerin cezalandırılmasına ilişkin bir hüküm de bulunmaması, "kaçınılmaz" kavramının yorumlanmasında yarg1 mercilerini tereddüde düşürebilecek niteliktedir ${ }^{88}$. Yarg1 mercileri tarafından belki de olası ağır yaptıım dikkate alınmak suretiyle failin hatasının kaçınılmaz olarak değerlendirmesi yönünde bir eğilim oluşturacaktır ${ }^{89}$. TCK'da katı kusur teorisinin ortaya çıkaracağı sorunların bu nedenlerle Alman Hukukundan daha belirgin olacağı konusunda tereddüt bulunmamaktadır.

Alman Ceza Kanununda TCK' dan farklı olarak bu konuda bir düzenleme bulunmamaktadır ${ }^{90}$. Alman öğretisindeki ağırlıklı olan görüşe göre sınırlı kusur teorisi kapsamında hukuka uygunluk nedenlerinin koşullarında hata maddi unsurlarda hata ile aynı hukuki sonucu doğurur ve Alman Ceza Kanunu'nun 16 I. hükmü kıyasen uygulanır ${ }^{91}$. Alman Federal Mahkemesi kararlarında da esas olarak, sorunun haksızlık yanılgı hükümleri çerçevesinde değil, sınırlı kusur teorisi kapsamında, unsur yanılgısında olduğu gibi, m. 16 hükmüne göre çözümlenmesi gerektiği vurgulanmaktadır ${ }^{92}$.

Alman öğretisinde katı kusur teorisinin yukarıda belirtilen sorunlarına tepki olarak tipin olumsuz unsurları ve sınırlı kusur teorisinin ortaya çıktığını görmekteyiz ${ }^{93}$.

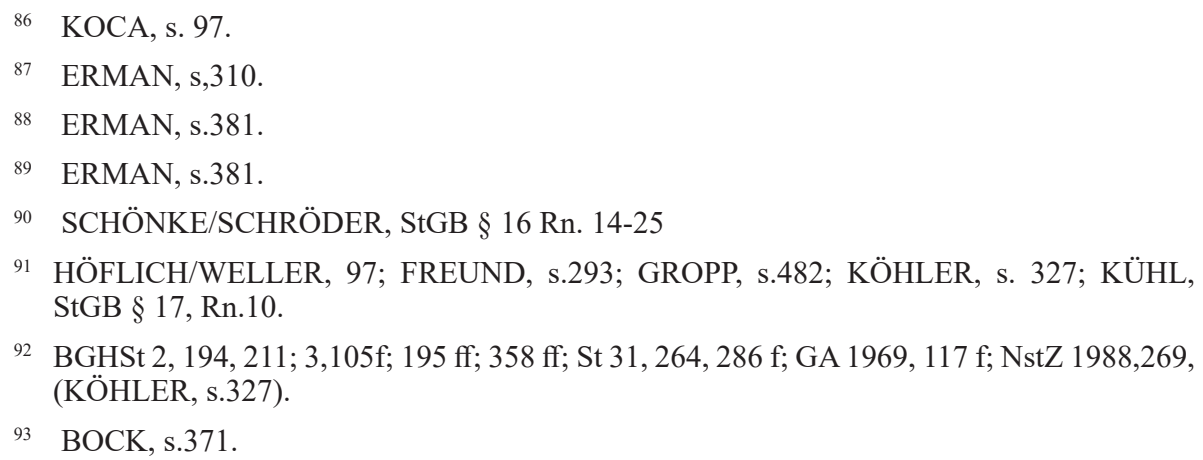


Suçun olumsuz (negatif) unsurları teorisi, suçun haksızlık unsurunun, kanuni tanımında yer alan unsurlar ile negatif suç unsurlarından (hukuka uygunluk nedenlerinin bulunmaması) meydana geldiği savından hareket etmektedir $^{94}$. Hukuka uygunluk nedenleri suçun olumsuz unsuru haline geldiğinden, hukuka uygunluk nedenlerinin maddi koşullarında hata, unsur hatasından başka bir şey değildir. Dolayısıyla hata kastın kapsamına dâhil olduğundan, unsur hatasına ilişkin hükümler doğrudan uygulanabilecektir ${ }^{95}$.

Katı kusur teorisine tepki olarak ortaya çıkan ve Alman öğretisinde hâkim görüş olan sınırlı kusur teorisi ise; kastı tipe uygunluk ve hukuka aykırılık kavramlarını kapsayan bir kavram olarak kabul etmektedir. Sinırlı kusur teorisi, suçun olumsuz unsurları teorisinden farklı olarak hukuka aykırılığı tipikliğin bir unsuru olarak kabul etmemekte, tipiklik ve hukuka aykırılı̆̆ 1 birbirinden bağımsız olarak suçun unsurları olarak görmektedir ${ }^{96}$. Hukuka aykırılık ve tipe uygunluk haksızlık kavramı altında denk kurumlardır ve bir eylemin haksızlık teşkil edebilmesi için hem tipe uygun, hem de hukuka aykır1 olmas1 zorunludur ${ }^{97}$.

Hukuka uygunluk nedenlerinin maddi koşullarında yanılma ile maddi unsurlarda yanılma (tipte yanılma) yapısal ve nesnel anlamda ortak bir özelliğe sahiptir. Her iki yanılma türünde de, fail için geçerli olan hukuk normlarına değil, maddi olaylara ilişkin bir yanılgı söz konusudur ${ }^{98}$. Burada unsur yanılgısından farklı olarak haksızlığı doğuran değil, ortadan kaldıran koşullarda bir yanılgı söz konusudur. Bu yapısal benzerlik nedeniyle, unsur yanılgısını düzenleyen hükmün kıyas yoluyla uygulanması gerekmektedir ${ }^{99}$.

TCK'nın 30/3. maddesinde "hatasından yararlanmadan" bahsedilmiş, ancak hukuka uygunluk nedenlerinin maddi koşullarında yanılmanın hukuki niteliğine değinilmemiştir. Öğretide, hukuka uygunluk nedenlerinin maddi

94 HEINRICH, s.188.

95 HEINRICH, s.188; JOEKS, StGB § 16 Rn. 128; ÖZGENÇ, (2019), s.478; ARTUK/GÖKÇEN/ALŞAHIN/ÇAKIR, s.648.

Suçun olumsuz unsurları teorisi hukuka uygunluk nedenlerinde maddi hata soruna tutarlı bir çözüm getirmesi nedeniyle Alman öğretisinde savunulan bu görüştür. Ancak üç bileşenli suç yapısına uymaması ve kastın suç teorisinde dikkate alınmayışı nedeniyle eleştirilmektedir (HEINRICH, 189; CHRISTOPH, s.32).

96 GÖKTÜRK, (2014), s.12.

97 ERMAN, s.340.

98 PUPPE, 16, Kn.156; FREUND, s.293; ERMAN, s.277.

99 HEINRICH, 183; GÖKTÜRK, (2014), s.13. 
koşullarında hatanın, failin kastını ortadan kaldırdığı konusunda bir uzlaşı görülmektedir ${ }^{100}$. Yukarıda belirttiğimiz teoriler kapsamında bir değerlendirme yapılacak olursa, Alman Ceza Hukukuna benzer şekilde sınırlı kusur teorisinin esas alınması gerektiği düşüncesinin hâkim olduğunu görmekteyiz ${ }^{101}$.

HEINRICH, Alman Ceza Hukukunda unsur hatas1-yasak hatas1 kapsamında en makul sonuçlara ulaşılmasını sağlayan yegâne yaklaşımın sınırlandırılmış kusur teorisi olduğunu savunmaktadır ${ }^{102}$. Türk Hukuk sisteminde de, benzer şekilde sınırlı kusur teorisinin cezalandırma sistemi açısından en doğru sonuçları veren görüş olduğunu düşünmekteyiz.

Hukuka uyguluk nedenlerinin maddi koşullarında hata yapan failin hukuka bağlı kalma iradesi bulunmaktadır. Failin maddi koşullarda yanılmasında gerekli dikkat ve özeni göstermediği için taksire dayalı sorumluluğu sözkonusu olacaktır ${ }^{103}$. Hukuka uygunluk nedenlerinin maddi koşulları da somut olaya ilişkindir. Bir başka deyişle somut olay hukuka uygunluk nedenlerinin maddi koşullarını da kapsar ${ }^{104}$. Bu nedenle failin hatasının haksızlık yanılgısından ziyade, unsur hatası olarak değerlendirilmesi daha yerinde bir değerlendirme olacaktır.

M.30/3'deki düzenlemede unsur hatasına yönelik m.30/1'e atıf bulunmadığından Alman Ceza Kanunu'ndaki gibi kıyasen uygulanması gerektiği düşünülmekle birlikte, kastın kalkmasına sebep olan hata, m.30/3'ün lafzı nedeniyle kaçınılmaz hatadır ${ }^{105}$.

Hatanınkaçınılabilir olması durumdaise, açık bir hükümbulunmadığından kaçınılabilir yanılgının ne şekilde yorumlanması gerektiğinin tartışılması gerekmektedir. "Hukuka uygunluk nedenlerinin varlığında" yanılmadan farklı olarak burada kaçınılabilirlik kavramının "kusuru" etkileyen bir neden olarak değerlendirilmesi mümkün değildir.

Maddi koşullarda hata konusunda kaçınılabilir yanılg1, özen yükümlülüğ̈̈ne bir aykırılık anlamına gelmekte ve taksirli bir eylemin varlığı

\footnotetext{
100 ARTUK/GÖKÇEN/ALŞAHİN/ÇAKIR, s.648; KOCA/ÜZÜLMEZ, s. 299, DEĞİRMENCİ, S.177.

101 KOCA, s.97.

102 HEINRICH, s. 182.

103 HEINRICH, s.183; ERMAN, s.387.

104 GÖKTÜRK, (2014), s.17.

105 DEĞİRMENCI, s. 177.
} 
sonucunu doğurmaktadır ${ }^{106}$. Bu kapsamda, dikkat ve özen eksikliğinden dolayı kaçınabileceği bir yanılmadan kaçınamayan failin, eyleminin taksirli şeklinin cezalandırılması halinde, meydana gelen neticeden taksiri nedeniyle sorumlu tutulacağ ${ }_{1}$ ifade edilmektedir ${ }^{107}$.

"Hukuka uygunluk nedenlerinin varlı̆ğnda yanılma" ile "maddi koşullarda yanılma" arasında aynı maddede düzenlenmiş olmasına rağmen, farklı sonuçlara gidilmesi bir tutarsızlık olarak görülebilir. Ancak sinırlı kusur teorisi kapsamında, Alman Ceza Kanunu'nda olduğu gibi her iki kurumda farklı sonuçlara gidilmesi tutarlı bir şekilde savunulabilecektir.

\section{cc. Hukuka Uygunluk Nedenlerinin Maddi Koşullarında Tersine Hata ${ }^{108}$}

Somut olayda hukuka uygunluk nedeninin bulunması, ancak failin bunu bilmemesi durumunda hukuka uygunluk nedenlerinin maddi koşullarında tersine hata söz konusudur. Fail, objektif olarak gerçekleşmiş bulunan bir hukuka uygunluk nedeninden haberi olmadan hareket ederek tipe uygun sonucu gerçekleştirmiş olabilir ${ }^{109}$.

Örnek olarak mağdurun evinde pusu kurarak, pencereden mağduru gördüğü anda ateş edip öldüren fail, gerçekte mağdurun aynı anda silahını üçüncü bir kişiye doğrultmuş ve ateş etmek üzere olduğunu bilmeden davranmış olabilirr ${ }^{110}$.

"Hukuka uygunluk nedenlerinin maddi koşullarında tersine hata" olarak tanımlanan bu hata türünde, failin hukuka uygunluk sebebinden yararlanıp yararlanamayacağ 1 konusunda öğretide iki görüş bulunmaktadır ve hangi çözüm tarzının ceza adaleti yönünden uygun olduğu tartışmalıdır.

765 sayıl1 TCK döneminde de kabul gören birinci düşünceye göre hukuka uygunluk nedenleri objektif bir etkiye sahiptirler. Bu itibarla etkilerini göstermeleri için söz konusu hukuka uygunluk nedenini failin bilmesine gerek yoktur ${ }^{11}$. "Objektif haksızlık ögretisine" göre, hukuka uygunluk

\footnotetext{
106 ERMAN, 384.

107 ÖZGENÇ, (2019), s. 483; DEĞİRMENCİ, 176.

108 Umgekehrter Erlaubnistatbestandsirrtum

109 ERMAN, s.388.

110 ERMAN, s.388.

111 GÜNGÖR, s.63; DURSUN/BOZBAYINDIR, s. 84.
} 
değerlendirmesi fiilin normu ihlal edip etmediği ile sınırlı bir değerlendirmedir. Failin iradesinin, normu ihlal bilincinin bir önemi bulunmamaktadır ${ }^{12}$. Bu görüş çerçevesinde, esas olan tipik neticenin gerçekleşmesi olup, tipik netice, objektif haksızlık kıstasını oluşturmaktadır. Failin iradesi ya da iç dünyası ile ilgili hususlar (sübjektif unsur) dış dünyada algılanamadığı için haksızlıkla ilişkilendirilmemektedir ${ }^{113}$.

Diğer görüşe göre ise, hukuka uygunluk sebebinin objektif olarak varlığg yeterli olmayıp, failin fiilini hukuka uygun hale getiren durumun varlığını bilmesi ve kendisine bu suretle verilen yetkinin icrası düşüncesiyle eylemini icra etmesi gerekmektedir ${ }^{114}$. Bu görüşe göre hukuka uygunluk nedeninin haksızlığ1 (fiilin değersizliği+neticenin değersizliği) ortadan kaldırabilmesi için objektif ve sübjektif unsurların birlikte gerçekleşmesi zorunludur. $\mathrm{Bu}$ unsurlardan birinin eksik kalması halinde fiil haksızlık teşkil eder ${ }^{115}$. Dolayısıyla failin hukuka uygunluk nedenlerinden faydalanabilmesi için hukuka uygunluk kast1 ${ }^{116}$ ile hareket etmesi gerekir ${ }^{117}$.

HAKERİ ise; failin hukuka uygunluk sebebinin koşulları içinde hareket ettiği bilincine sahip olmasl gerektiği görüşündedir ${ }^{118}$. Bu düşünce çerçevesinde, salt bir tesadüf nedeniyle hukuka uygunluk koşulunun objektif olarak gerçekleşmesinin, fiilin sonucunun faile yüklenmesini engellemeyeceği fikri ileri sürülmektedir ${ }^{119}$.

Hukuka uygunluk nedenlerinin maddi koşullarında hatanın hukuksal sonuçlarının nasıl belirleneceği, sadece hata teorisi ile ilgili değildir. Hukuka aykırılığın yukarıda kısmen değinildiği üzere suç teorisi kapsamında hukuki niteliğinin ne şekilde kabul edildiği, diğer taraftan, hareketin haksızlığı neticenin haksızlığı arasındaki ayrım ve hangi ölçütün esas alındığı konuları ile de doğrudan ilgilidir.

Hareketin haksızlığ1 - neticenin haksızlığı ayrımı esas alındığı takdirde, hukuka uygunluk nedenlerinin maddi koşullarında tersine hata halinde,

\footnotetext{
112 ŞENOL, s.65.

113 GÖKTÜRK, (2015), s.14.

114 ARTUK/GÖKÇEN/ALŞAHIN/ÇAKIR, s.650.

115 GÖKTÜRK, (2015), s.19.

116 Rechtfertigungsvorsatz

117 GÖKTÜRK, (2015), s.23.

118 HAKERİ, s.459.

119 KÖHLER, s.323.
}

348 Ankara Hacı Bayram Veli Üniversitesi Hukuk Fakültesi Dergisi C. XXIV, Y. 2020, Sa. 3 
hareket haksız olmakla birlikte, netice haksız olmadığından, failin teşebbüsten cezalandırılması gerektiği kabul edilmektedir. Alman hukukunda ağırlıklı olan bu düşüncenin temelini, failin tamamlanmış suçtan sorumlu olabilmesi için, sadece tipik sonucun meydana gelmesi değil, hareketin ve sonucun olumsuz değerini içeren objektif ve sübjektif haksızlık tipinin gerçekleşmiş olmasının aranması oluşturmaktadır ${ }^{120}$.

Radikal finalist görüşü savunan bazı yazarlar tarafindan haksızlık kavramının içeriğini hareketin haksızlığının oluşturduğu kabul edilmektedir. $\mathrm{Bu}$ görüşe göre, haksızlık normda yatan bir emirle çatışma halidir ve hareket istencinin içinde bulunmaktadır. Neticenin gerçekleşmesi çoğu zaman tesadüflere bağlıdır ve neticenin gerçekleşmesinin haksızlığın oluşumu bakımından bir önemi bulunmamaktadır. Bu nedenle neticenin gerçekleşmesi ancak objektif cezalandırma koşulu olabilirr ${ }^{121}$.

Ancak günümüzde Alman öğretisinde de haksızlık kavramının hem hareketin, hem de neticenin haksızlığını kapsadığı düşüncesinin hâkim olduğu söylenebilirr ${ }^{122}$. Aksi düşünce taksirli suçlar ile suça teşebbüs hükümlerinin uygulanmasında da sorunlar ortaya çıkarmaktadır. Kasıtlı suçlara teşebbüsün neden daha az cezalandırıldığı, taksirli suçlara teşebbüsün ise niçin cezalandırılmadığı soruları yanıtsız kalmaktadır ${ }^{123}$.

Öğretide genel kabul gören görüşe göre sadece hukuka aykırılığın objektif varlığı ile yetinen bir açıklama hukuka uygunluk sebeplerinde hata olgusunun doğurduğu problemleri çözmeye yeterli değildir ${ }^{124}$. Bu anlayış, hukuka uygunluk nedenlerinin maddi koşullarındaki hatayı mefruz suç ${ }^{125}$ olarak nitelendirmektedir.

Tipik sonucun gerçekleşmiş olması nedeniyle, failin tamamlanmış suçtan sorumlu tutulması ceza adaleti ile bağdaşmayacaktır ${ }^{126}$. Ayrıca hareketin ve sonucun olumsuz değerini içeren objektif ve sübjektif haksızlık tipi gerçekleşmediğinden, faili tamamlanmış suçun oluştuğundan bahisle

\footnotetext{
120 ERMAN, s.391.

121 KEÇELIOĞLU, (2013), s.29.

122 GROPP, Rn.31; KEÇELİĞLU, (2013), s.28.

123 KEÇELIOĞLLU, (2013), s.30.

124 DÖNMEZER/ERMAN, C.II, Kn.699; OZANSÜ, s.391.

125 Wahndelikt

126 DEĞİRMENCİ, s.173.
} 
cezalandırmak mümkün görülmemektedir ${ }^{127}$.

Failhukukauygunluk sebebininmaddikoşullarının gerçekleştiğibilinciyle hareket etmediği için, fiil haksızlık olarak gerçekleşmekle birlikte, neticenin haksızlığından bahsetmek mümkün değildir. Bu nedenle failin teşebbüsten cezalandırılması gerektiği düşünülebilir ${ }^{128}$. Alman Ceza Hukukunda savunulan finalist görüşe göre teşebbüs çözümü, iradi hareketin varlığını hukuka aykırılık bakımından yeterli bulması görüşüne dayanmaktadır ${ }^{129}$. Bu görüş çerçevesinde elverişsiz teşebbüs de cezalandırılabilir kabul edilmektedir.

Türk Ceza Kanununda ise teşebbüs; "kastedilen bir suçu elverişli hareketlerle icraya başlayıp sonucun gerçekleşmemesi" şeklinde tanımlanmaktadır. Somut olayda, tamamlanmış bir suçun mevcudiyetinden dolayı teşebbüs hükümlerinin uygulanabilmesi Kanunumuz bakımından olası gözükmemektedir.

Fiilin haksızlık içeriği bakımından teşebbüs aşamasında kalan suçla eşdeğer görülebileceğinden, teşebbüs hükümlerinin kıyasen uygulanması düşünülebilir ${ }^{130}$. Ancak failin tamamlanmış bir suçtan dolayı teşebbüs hükümleri uyarınca cezalandırılmasının ceza adaleti açısından ne derece tutarlı olduğu tartışmalıdır ${ }^{131}$.

Zira TCK' da, Alman Ceza Kanunu'nun 22. maddesindeki gibi işlenemez suç halinde sadece hukuka aykırı davranma iradesinin cezalandırılmasına yönelik bir hüküm bulunmadığından, failin teşebbüs hükümleri çerçevesinde cezalandırılmasının normatif bir dayanağ 1 bulunmamaktadır ${ }^{132}$. Bu nedenlerle;

${ }^{127}$ ERMAN, 391.

128 ÖZGENÇ, (2019), s.482; ARTUK/GÖKÇEN/ALŞAHIN/ÇAKIR, s.650. Teşebbüs hükümlerinin uygulanması gerektiğini savunanlar da doğrudan teşebbüs hükmünün uygulanması gerektiğini savunan ve kıyasen teşebbüs hükümlerine başvurulabileceğini ileri süren görüş olarak ikiye ayrılmaktadır (DURSUN/BOZBAYINDIR, s.77).

${ }^{129}$ SÖZÜER, s.103. Alman Ceza Kanunu'nun 22. maddesinde teşebbüs; "eyleme ilişkin tasavvuruna uygun olarak tipin gerçekleşmesine doğrudan başlayan kişi, suça teşebbüs etmiş sayılır. "ş̧eklinde tanımlanmakta; 23/3. maddesinde de; elverişsiz teşebbüs durumunda failin cezasının indirilebileceğini veya tamamen kaldırılabileceğini ifade etmektedir. Ceza indiriminin ne şekilde yapılacağı konusunda ise m.49/2'ye atıf yapılmaktadır.

${ }^{130}$ GÖKTÜRK, (2014), s.22.

${ }^{131}$ DEĞİRMENCİ, s. 173. Alman öğretisinde kıyasen teşebbüs normuna müracaat görüşüne yöneltilen en esaslı itiraz, bu çözüm teklifinin kanunilik ilkesini ihlal ettiği iddiasıdır (DURSUN/BOZBAYINDIR, s.77).

${ }^{132}$ ARTUK/GÖKÇEN/ALŞAHİN/ÇAKIR, s. 651; ŞENOL, s.66. 
hukuka uygunluk nedenlerinin maddi koşullarında tersine yanılgı içinde olan kişi yönünden “cezalandırllmayan eylem çözümü”, en uygun çözüm niteliğindedir ${ }^{133}$.

\section{dd. Hukuka Uygunluk Nedenlerinin Sinırının Aşılmasında Hata (m.27/1) $)^{134}$}

Hukuka uygunluk nedenlerinin sınırının aşılmasında hata; aynı hukuka uygunluk nedenlerinin maddi koşullarındaki hata gibi öğretide de farklı görüşlerin bulunduğu diğer bir konudur.

Yukarıda "hukuka uygunluk nedenlerinin varlığında hata" konusunda kısmen değindiğimiz üzere, Alman öğretisinde hukuka uygunluk nedeninin sınırlarında hataya düşülmesi, aynen varlı̆̆ında hataya düşülmesi durumunda olduğu gibi izin hatas1 ${ }^{135}$ olarak nitelendirilmektedir. Burada hata halinde fail, hukuka uygunluk nedeninin sınırlarını olduğundan geniş kabul ederek, hareketini gerçekleştirmektedir ${ }^{136}$. Alman öğretisindeki ağırlıklı görüşe göre sınırın aşılmasında hata halinde yasak hatası (haksızlık yanılgısı) hükümleri uygulanacak, hata kaçınılmaz ise cezalandırılmayacaktır (Alman Ceza Kanunu m.17). Hatanın kaçınılabilir olması durumunda ise Alman Ceza Kanunu'nun 49/1. maddesi uyarınca ceza indirilebilecektir ${ }^{137}$.

TCK'nın 27. maddesinin 1.fikrasında hukuka uygunluk nedeninde sınırın kast olmaksızın aşılması hali ayrıca hükme bağlanmıştır. Kanun metninde "ceza sorumluluğunu kaldıran nedenlerde sinırın aşılması" ifadesi kullanılmışsa da, maddeden anlaşılması gerekenin "hukuka uygunluk nedenleri" olduğu konusunda bir tereddüt bulunmamaktadır ${ }^{138}$.

Alman Ceza Kanunu'nda ise bu maddenin karşılığ dayanan sınır aşımı" haline yer verilmemiştir. Alman Ceza Kanunu'nun 33. maddesinde ise ${ }^{139}$; TCK m.27/2 deki meşru savunmada sınırın "mazur

\footnotetext{
${ }^{133}$ ERMAN, DEĞİRMENCİ, s. 174.

${ }^{134}$ Erlaubnisgrenzirrtum

${ }^{135}$ Erlaubnisirrtrum

${ }^{136}$ HEINRICH, s.194; JOEKS, StGB § 17, Rn.33.

${ }^{137}$ FISCHER, StGB § 17, Rn.12, s.125. HÖFLICH/WELLER, s.97.

138 ÖZGENÇ, (2006), s. 395; KOCA/ÜZÜLMEZ, s.305; DEĞİRMENCİ, s.180.

139 Alman Ceza Kanunu'nun “meşru savunma (Notwehr) sınırının aşılması” başlıklı 33.maddesi; "Fail meşru savunmanın sinırlarını şaşkınlık, korku veya panik nedeniyle aşarsa, cezalandirllmaz.” hükmünü içermektedir. Alman Ceza Kanunu'nun Türkçe
} 
görülebilecek korku, heyecan ya da telaş" nedeniyle aşılması haline benzer şekilde bir cezasızlık hali olarak düzenlendiğini görmekteyiz.

TCK'nın 27. maddesinin 1 ve 2. fikralarını karşılaştırdığımızda hukuki niteliği itibariyle farklı hükümlerin aynı madde başlığı altında düzenlendiğini görmekteyiz.

TCK m.27/2'de meşru savunma sınırının korku, heyecan veya telaş nedeniyle aşılması durumunun, failin kusurluluğu kapsamında ele alınması gerekmektedir. Failin sınırı aşması hatadan değil, korku, heyecan ya da telaşın iradesi üzerindeki etkisi nedeniyle davranışlarını yönlendirme yeteneğinin ortadan kalkmasından kaynaklanmaktadır. Bu nedenle TCK'nın 27/2. maddesi özel bir zorunluluk hali olarak değerlendirilmelidir. Söz konusu madde hukuki niteliği itibariyle kastı değil, kusurluluğu ortadan kaldıran sebeplerden biridir $^{140}$.

Yargıtay içtihatlarında da kişinin maruz kaldığ 1 saldırının etkisiyle, "heyecan, korku veya telaşa" kapılarak meşru müdafaada sınırlarını aştığında Kanun'un 27/2. maddesi gereğince uygulama yapılmaktadır. Ancak failin amac1, saldırının defedilmesinden çok, kin duygusunu tatmine yönelik ise meşru savunmada sınırın aşılması değil, haksız tahrik hükümlerinin uygulanmas1 cihetine gidilmektedir ${ }^{141}$.

tercümesi için bkz. YENISEY/PLAGEMANN, s.24.

${ }^{140}$ KOCA, s. 99; KOCA/ÜZÜLMEZ, s.306.

${ }^{141}$ YCGK, 13.2.2018, E.2017/1-183, K.2018/33.”...5237 Say1l1 TCK'nun 27.maddesinin 2. fikrasında, hukuka uygunluk nedenlerinden sadece meşru savunma için sınırın aşılmasına dair özel bir düzenleme öngörülmüştür. Buna göre bu hükmün uygulanabilmesi için;

1- ) Meşru savunma ile korunabilecek bir hakkın bulunması,

2- ) Saldırıya dair şartların var olması,

3- ) Savunmaya dair şartlardan "ölçülülük ya da orantılılık" şartının, savunma lehine ihlal edilmesi suretiyle sınırın aşılması,

4- ) Sınırın aşılmasının mazur görülebilecek bir heyecan, korku veya telaştan ileri gelmesi gerekmektedir.

Tüm bu şartların birlikte gerçekleşmesi hâlinde, meşru savunmada sınırı aşan faile CMK'nun 223/3-c maddesi uyarınca ceza verilmeyecektir. Bu durumda, kişinin, maruz kaldığı saldırı karşısında içine düştüğü heyecan, korku veya telaş dolayısıyla davranışlarını yönlendirme yeteneğinin ortadan kalkması söz konusu olacağından, meşru savunmada sınırın aşılmasından dolayı kusurlu sayılmayacağı kabul edilir. Dolayısıyla, belirleyici olan maruz kalınan saldırının kişiyi içine düşürdüğg̈ psikolojik durumdur. Zira kişi sırf maruz kaldığ 1 saldırının etkisiyle, "heyecan, korku veya telaşa" kapılarak meşru müdafaada sınırlarını aştı̆̆ında bu maddeden yararlanabilecek, buna karşılık saldırının etkisinin yanında, saldırıdan kaynaklanmış olsa bile, öfke gibi sebeplerle sınır aşıldığında 
TCK'nın 27. maddesinin 1. fikrası ise hukuki niteliği itibariyle hukuka uygunluk nedeninin sınırının aşılmasında hata halini düzenlemektedir. Buradaki hata haline ilişkin olarak öğretide farklı görüşler bulunmaktadır ${ }^{142}$. Farklı görüşlerin nedenleri incelendiğinde ise; hukuka uygunluk nedenlerinde sınırın aşılmasının, hukuka uygunluk nedenlerinin maddi koşullarında hata ve hukuka uygunluk nedenlerinin varlığında hata ile ne derece birbirlerine yaklaştıkları ile ilgili olduğunu görmekteyiz.

Hukuka uygunluk nedenlerinin sınırının kast olmaksızın aşılması halinde hata, sınırın ölçü yönünden aşılması şeklinde tezahür edebilmektedir. İlgili maddede sınırın taksirle aşılması halinin de düzenlendiğini görmekteyiz.

Örneğin meşru savunma koşullarını doğru değerlendiren ve zanlının ayağına ateş etme kastıyla hareket eden fail, yanlışlıkla ve orantısız bir şekilde zanlıyı hayati bölgeden vurmak suretiyle ölümüne neden olması durumunda m.27/1'den istifade edebilecektir. Böyle bir durumda hukuka uygunluk nedenlerinin maddi şartlarında hata söz konusu değildir. Burada fail kendisine yönelen saldırıyı doğru değerlendirmiş olup maddi koşullara ilişkin bilgisi de tamdır. Diğer taraftan hukuka uygunluk nedeninin sınırının bilinmemesi, dolayısıyla normun yasakladığı davranışa izin veren normun sınırında bir hata da söz konusu değildir. Burada fail, hukuka uygunluk nedenlerinde sinırı hata hali olmaksızın aşmıştır. Bu yönüyle m.27/1, hatanın ötesine geçen bir düzenleme niteliğindedir ${ }^{143}$.

Hukuka uygunluk nedenlerinin sınırının aşılması, maddi koşullarda yanılma nedeniyle de ortaya çıabilmektedir. KOCA, bu yönü nedeniyle "hukuka uygunluk nedenlerinin maddi şartlarındaki hatanın bir görünüm şekli" olarak nitelendirmektedir ${ }^{144}$. Dolayısıyla hukuki sorunun hukuka uygunluk nedenlerinin maddi koşullarında hataya ilişkin hükümler çerçevesinde çözümlenmesi gerektiği ifade edilmektedir. Gerçekten hukuka uygunluk nedenlerinin sınırının aşılmasının temelinde hukuka uygunluk

ise aynı korumadan faydalanılması söz konusu olmayacaktır. Başka bir deyişle, failin amacı, saldırının defedilmesinden çok, kin duygusunu tatmine yönelik ise meşru savunmada sınırın aşılması değil, ancak haksız tahrik söz konusu olabilecektir”.

142 KOCA/ÜZÜLMEZ, s.305 vd.; GÖKTÜRK, (2014), s.28; DEĞİRMENCİ, s.179-181; ERMAN, s.286.

143 ERMAN, s.288.

${ }^{144}$ KOCA, s.98. 
nedenlerinin maddi koşullarında hata yatıyor olabilir ${ }^{145}$. Hukuka aykırı saldırının niteliğini yanlış değerlendirerek aşırı şiddet kullanan kişiye ilişkin olarak meşru savunmada sınırın aşılması, maddi koşulların yanlış değerlendirilmesinden kaynaklanmaktadır. Savunmada saldırıyı defedecek ölçüde olması unsuru, kastın kapsamında bulunması gereken normatif unsur niteliğinde olduğundan, hata kastı ortadan kaldırır ${ }^{146}$. Failin daha dikkatli ve özenli davranması halinde savunmanın ölçüsündeki sınır aşımı öngörülebilir ise, failin taksirli sorumluluğu söz konusu olacağından cezasında m.27/1 uyarınca indirime gidilebilecektir.

Son olarak da; hukuka uygunluk nedenlerinin sınırının aşılması, nedenlerinin varlığında yanılma haline benzer şekilde, hukuka uygunluk nedenlerinin sınırında yanılma şeklinde tezahür edebilmektedir. Bu durumda yanılma hukuka uygunluk nedenlerinin maddi koşullarında değil, normun yasakladığı davranışa izin veren normun sınırındadır. Kişi somut vakıayı zihninde doğru bir şekilde tasavvur etmekte, ancak izin normunu bilmemekte ya da yanlış bilmeye dayalı bir değerlendirme hatası bulunmaktadır ${ }^{147}$. Tedip hakkının etkili eylemde bulunma hakkını verdiğini düşünen ebeveynin bu yöndeki davranış1, izin normunun sınırlarında yanılmaya örnek gösterilebililir ${ }^{148}$.

İzin normunun sınırında yanılma hukuki niteliği itibariyle izin normunun varlığında yanılma ile benzerlik göstermektedir. Her iki hata halinde de failin yanılması, izin veren norm üzerindedir. Failin yanılgısı hukuk düzenince tanınmayan bir hukuka uygunluk nedeninin varlığında olabileceği gibi, sınırının yanlış bilinmesi ya da bilinmemesinden kaynaklanabilmektedir. Her iki ihtimalde de hata, fiilin haksızlık oluşturduğu konusundadır. Bu nedenle haksızlık yanılgısına ilişkin TCK'nın 30/4. maddesinin uygulanması gerekmektedir.

Alman Ceza Hukukunda hukuka uygunluk nedenlerinin sınırının aşılması durumunda yasak hatası kapsamında görülmesi nedeniyle m.17 hükmü uygulanmakta, hatanın kaçınılmaz olup olmamasına göre ceza sorumluluğu şekillenmektedir ${ }^{149}$. Daha önce belirttiğimiz üzere TCK m.27/1 hükmüne benzer bir düzenlemeye ise Alman Ceza Kanunu'nda yer verilmemiştir.

\footnotetext{
145 ERMAN, s.287.

146 KOCA, s.99.

147 GÖKTÜRK, (2014), s.28

148 DEĞİRMENCİ, s. 168.

149 JOEKS, StGB § 17, Rn.33; HEINTSCHEL-HEINEGG, StGB § 17 Rn. 31-33.
} 
Hukuka uygunluk nedenlerinde sınırın izin yanılgısı nedeniyle aşılması durumunda, TCK'da 27/1. maddesinin uygulanmas1 konusunda madde gerekçesinde bir açıklama bulunmamaktadır. Kanun'un 30/4. maddesinde haksızlık yanılgısına ilişkin hatanın kaçınılmaz olması halinde cezasızlık hali öngörüldüğünden m.27/1 uygulanmas1 gündeme gelmeyecektir. Ancak hatanın kaçınılabilir olması durumunda, failin taksirli sorumluluğu söz konusu olacağından cezasında m.27/1 uyarınca indirime gidilebilecektir.

\section{SONUÇ}

Hukuk uygunluk nedenlerinde hata, hukuka uygunluk nedenlerinin maddi koşullarında, hukuka nedenlerinin varlığında ya da sınırında olabilmektedir. Her üç hata halinin hukuki niteliği birbirinden farkl1lık göstermektedir.

Türk Ceza Kanunu'nda 30.maddesinin 3. fikrasında hukuka uygunluk nedenlerinde hatanın "ceza sorumluluğunu kaldıran ya da azaltan nedenler" başlığı altında düzenlendiğini, hukuka uygunluk nedenlerinin sınırının aşılması halini ise 27. maddenin 1. fikrasında yer verildiğini görmekteyiz. Dolayısıyla hukuka uygunluk nedenlerinin maddi koşullarında hata ile nedenlerin varlığında hata konusu 30/3. maddesi kapsamında, aynı madde altında normatif düzenlemeye kavuşturulmuştur.

Hukuka uygunluk nedenlerinde maddi koşullarında hata makalemizin öğretide en tartışmalı konusunu oluşturmaktadır. Alman Ceza Kanunu'nda normatif olarak düzenlenmemiş olan bu hata hali, tipiklikteki unsur hatas1 ile aynı mahiyette görülmektedir. Zira hukuka uygunluk nedenlerinin maddi koşullardaki yanılma ile maddi unsurlarda yanılma (tipte yanılma) yapısal ve nesnel anlamda ortak bir özelliğe sahiptir. Her iki yanılma türünde de, fail için geçerli olan hukuk normlarına değil, maddi olaylara ilişkin bir yanılg1 söz konusu olup, burada unsur yanılgısından farklı olarak haksızlığı doğuran değil, ortadan kaldıran koşullarda bir yanılg1 söz konusudur. Bu yapısal benzerlik nedeniyle, öğretide unsur yanılgısını düzenleyen hükmün kıyas yoluyla uygulanması gerektiği görüşü hâkimdir.

Normatif düzenleme dikkate alınarak Kanunumuzda hukuka uygunluk nedenlerinin maddi koşullarında hata konusunda katı kusur teorisinin esas alındığ1 yönünde öğretide görüşler bulunmakta birlikte, katı kusur değil öğretide ağırlıklı görüş olan sınırlı kusur teorisinin esas alınması gerektiğini düşünmekteyiz.

M.30/3'deki düzenlemede unsur hatasına yönelik m.30/1'e atıf bulunmadığından, sınırlı kusur teorisi kapsamında kıyasen uygulama 
yapılmas1 mümkün görülmektedir. Ancak, kastın kalkmasına sebep olan hatanın m.30/3'ün lafzı nedeniyle kaçınılmaz hata olarak nitelendirilmesinin zorunlu olduğu düşünülmektedir.

Hatanın kaçınılabilir olmasına bir hukuki sonuç bağlanmamış olması diğer bir tartışma konusunu teşkil etmektedir. Zira m.30/3'deki düzenlemede Alman Ceza Kanunu'nun 17/2. maddesindeki gibi indirim halini düzenleyen bir hükme yer verilmemiştir. Failin gerekli dikkat ve özeni göstermesi durumunda yanılgıya düşmeyeceği sonucuna varılıyor ise, kaçınılabilirliğin ölçüsüne göre kusurundaki azalma oranında kasten işlenen suçun cezasında indirim yapılmasını mümkün kılan bir düzenlemenin olması, uygulamada doğabilecek tereddütleri giderebilecektir.

Hukuka uygunluk nedenlerinin varlığında hata ise haksızlık yanılgısı ile benzerlik göstermektedir. Burada hata, haksızlık yanılgısından farklı olarak yasaklayıcı normda değil, izin veren normun varlığına ilişkindir. Dolayısıyla "kaçınılmazlık" ölçütünün kullanılması yönünden bir sorun bulunmamakta, ancak kaçınılabilir hata durumunda ceza sorumluluğunun nasıl belirleneceği yukarıda belirtildiği üzere tartışma konusu oluşturmaktadır.

Son olarak; hukuka uygunluk nedenlerinin sınırının aşılması konusunda TCK'nın 27. maddesinin 1. fikrasında düzenleme bulunmaktadır. Söz konusu düzenlemede, failin kast olmaksızın hukuka uygunluk nedenlerinde sınırı aşması durumunda taksirli sorumluluk hali hüküm altına alınmıştır.

Hukuka uygunluk nedenlerinde sınır aşımı durumu, hatanın mahiyetine göre kasıt ya da kusurluluk üzerinde etkide bulunabilecektir. Alman Ceza Kanunu'nda izin hatası olarak görülen ve yasak hatası hükümlerinin uygulanması yoluyla çözüme kavuşturulan söz konusu sınır aşımı kurumu, m.27/1 'deki düzenlemeyle hata konusunun da ötesinde ceza sorumluluğunu daraltan bir içeriğe sahiptir. Failin taksirli sorumluluğunun öngörülmesi ise, sınır aşımına ilişkin failin dikkat ve özen yükümlülügüne ne derece uygun davrandığının incelenmesini gerektirmektedir. 


\section{KAYNAKÇA}

AKBULUT, Berrin: Ceza Hukuku Genel Hükümler, 6.Bask1, Adalet Yayınevi, Ankara, 2019.

ARTUK, Mehmet Emin/ GÖKÇEN, Ahmet/ALŞAHIN, Emin, ÇAKIR, Kerim: Ceza Hukuku Genel Hükümler, 14. Bask1, Adalet Yayınevi, Ankara, 2020.

BOCK, Dennis: Strafrecht Allgemeiner Teil, 1. Auflage, Springer Verlag, Berlin, 2018.

CENTEL, Nur /ZAFER, Hamide/ÇAKMUT, Özlem, Türk Ceza Hukukuna Giriş, 7. Bası, Beta Yayınevi, İstanbul, 2011.

CHRISTOPH, Stephan: Der Erlaubnistatbestandsirrtum in der Falllösung, Juristische Arbeitsblätter, Heft 1, 2016 (Beck online).

DEĞİRMENCİ, Olgun: "Ceza Hukukunda Yanılma Kavramı ve Hukuka Uygunluk Nedenlerinde Yanılma", TBB Dergisi, Say1: 110, 2014, s.129-188.

DEMİBAŞ, Timur: Türk Ceza Kanunu Genel Hükümler, 14. Bask1, Seçkin Yayınevi, Ankara, 2019.

DÖNMEZER, Sulhi /ERMAN, Sahir: Nazari ve Tatbiki Ceza Hukuku, C.II, 14. Bası, Beta Yayınevi, İstanbul, 1999.

DURSUN, Selman/BOZBAYINDIR, Ali Emrah: "Ceza Hukukunda Hukuka Uygunluk Nedenlerinin Manevi Unsurlar1 Meselesi", İstanbul Üniversitesi Hukuk Fakültesi Mecmuası, C. LXXIII, S. 1, 2015, s. 63-90.

ERMAN, Ragıp Barış: Yanılmanın Ceza Sorumluluğuna Etkisi, Yayınlanmamış Doktora Tezi, İstanbul Üniversitesi Sosyal Bilimler Enstitüsü, İstanbul, 2006.

FISCHER, Thomas: Strafgesetzbuch, 56. Auflage, Verlag C.H.Beck, München, 2009.

FRUEND, Georg: Strafrecht Allgemeiner Teil, 2. Auflage, Springer Verlag, Heidelberg, 2009.

GÖKTÜRK, Neslihan: "Hukuka Uygunluk Nedenlerinin Maddi Koşullarında Yanılgının Hukuki Niteliği”, Ceza Hukuku Dergisi, 2014, S.26, s.630.

GÖKTÜRK, Neslihan: "Hukuka Uygunluk Nedenleri Objektif Nitelikte 
midir?", Ceza Hukuku Dergisi, 2015, C.10, S.27, s.7-28.

GÖKTÜRK, Neslihan: Haksızlık Yanılgısının Ceza Sorumluluğuna Etkisi,

1. Baskı, Seçkin Yayınları, Ankara, 2016.

GROPP Walter: Strafrecht Allgemeiner Teil, 2. Auflage, Springer Verlag, Heidelberg, 2001.

GÜNGÖR, Devrim: Ceza Hukukunda Fiil Üzerinde Hata, 1. Bask1, Yetkin Yayınları, Ankara, 2007.

HAKERİ, Hakan: Ceza Hukuku Genel Hükümler, 22.Bask1, Seçkin Yayınevi, Ankara, 2019.

HEINRICH, Bernd: Ceza Hukuku, Genel Kısım II, 1.Bask1, Adalet Yayınevi, Ankara, 2015.

HEINTSCHEL-HEINEGG, Bernd: Beck'sche Online-Kommentare, 46. Edition, Verlag C.H.BECK, München, 2020.

HÖFLICH, Peter / WELLER, Frank: Strafrecht-Schnell Erfasst, 2. Auflage Springer Verlag, Heidelberg, 2005.

JOEKS, Wolfgang: Münchener Kommentar zum Strafgesetzbuch, 3. Auflage Verlag C.H. Beck, München, 2017.

JÜNEMANN, Alexander: "Alman Ceza Hukukunda Hukuka Uygunluk Sebeplerinin Sistemi”, Ceza Hukuku Dergisi, Cilt 9, S.26, 2014, s. 279-281. (Çeviren İlker Tepe)

KEÇELİĞLLU, Elvan: "Kusurluluğu Ortadan Kaldıran Sebeplerle Hukuka Uygunluk Sebepleri Arasındaki Ayrımın TCK'nın Uygulanması Bakımından Pratik Sonuçları”, TBB Dergisi, Sayı.87, 2010, s.299-321.

KEÇELIOĞLU, Elvan: "Ceza Hukukunda Haksızlık, Hareketin ve Neticenin Haksızlığı”, Ceza Hukuku Dergisi, S.2, 2013, s. 21-33.

KINDHAUSER,Urs/NEUMAN,Ulfrid/PAEFFGEN, Hans Ullrich: Strafgesetzbuch-Nomos Kommentar, 5. Auflage, 2017.

KOCA, Mahmut/ÜZÜLMEZ, İlhan: Türk Ceza Hukuku Genel Hükümler, 12. Bask1, Seçkin Yayınevi, Ankara, 2019.

KOCA, Mahmut: "Türk Ceza Hukukunda Hata", 3. Yılında Yeni Ceza Adalet Sistemi, 1. Baskı, Seçkin Yayınevi, Ankara, 2009.

KÖHLER, Michael: Strafrecht Allgeminer Teil, 1. Auflage, Springer Verlag, Heidelberg, 1997. 
KÜHL, Kristian: Strafgesetzbuch Kommentar, 29. Auflage, Verlag C.H.Beck, München, 2018.

OZANSÜ, Mehmet Cemil: "Yeni Türk Ceza Kanunu Çerçevesinde Hata Kavramı”, Suç Politikası, Karşılaştırmalı Ceza Hukuku Serisi (5), 1. Baskı, Seçkin Yayınevi, Ankara, 2006.

ÖZBEK, Veli Özer /DOĞAN, Koray /BACAKSIZ, Pınar: Türk Ceza Hukuku Genel Hükümler, 10. Bask1, Seçkin Yayınevi, Ankara, 2019.

ÖZGENÇ, İzzet: Türk Ceza Kanunu Gazi Şerhi (Genel Hükümler), 1. Baskı, Seçkin Yayınevi, Ankara, 2006.

ÖZGENÇ, İzzet: Türk Ceza Kanunu Genel Hükümler, 15. Bası, Seçkin Yayınevi, Ankara, 2019.

ÖZTÜRK, Bahri / ERDEM, Mustafa Ruhan: Uygulamalı Ceza Hukuku ve Güvenlik Tedbirleri Hukuku, 19. Baskı, Seçkin Yayınevi, Ankara, 2019.

PUPPE, Ingeborg: Strafrecht Allgemeiner Teil, 1. Auflage, Nomos Verlag, Baden-Baden, 2002.

SARIGÜL, Ali Tanju: "Ceza Hukukunda Hata Kavramı ve Suçun Maddi Unsurlarında Hatanın Ceza Sorumluluğuna Etkisi", Erciyes Üniversitesi Hukuk Fakültesi Dergisi, Cilt 14, Sayı 2, s.663-693.

SCHÖNKE, Adolf/SCHRÖDER, Horst: Strafgesetzbuch Kommentar, 30. Aufl, Verlag C.H.Beck, München, 2019.

SOYER GÜLEÇ, Sesim: “Türk Ceza Kanununda Haksızlık Yanılgısı”, Dokuz Eylül Üniversitesi Hukuk Fakültesi Dergisi, Cilt 10, Say1 1, 2008, s.59-91.

SÖZÜER, Adem: Suça Teşebbüs, 1. Bask1, Kazancı Yayınları, İstanbul, 1994.

ŞENOL, Cem: "5237 sayılı TCK'ya Göre Hukuka Uygunluk Sebeplerinin Maddi Koşullarında Hata", Terazi Hukuk Dergisi, Cilt 14, Sayı 149, 2019, s.60-69.

TOPRAK, Ufuk: "Alman Ceza Hukukunda Düzenlenen Kasıt ve Yanılma Türlerine Dair Kısa Bir İnceleme”, Terazi Hukuk Dergisi, Sayı: 64, 2012, s.29-45.

YENISEY, Feridun/PLAGEMANN, Gottfried: Strafgesetzbuch (StGB) Alman Ceza Kanunu, 2. Bası, Beta Yayınları, İstanbul, 2015. 
